\title{
Intervención de las izquierdas y politización obrera en SITRAC-SITRAM, la experiencia paradigmática del sindicalismo clasista de los '70
}

Role of the left-wing groups and worker politicization in SITRAC-SITRAM, the paradigmatic experience of the clasista unionism of the ' $70 \mathrm{~s}$

Rodolfo Laufer*

Resumen: En este trabajo reconstruimos la intervención de las izquierdas en la experiencia de SITRAC-SITRAM, paradigma del sindicalismo clasista en la Argentina de los 70. Puntualizamos cuáles fueron las fuerzas políticas que lograron fuerza propia en la nueva dirección sindical (POT, FAL, VC, PRT-ERP, PB-FAP y PCR), sus principales orientaciones políticas y sindicales y su rol en la politización obrera y en las definiciones de los nuevos sindicatos de Fiat.

Palabras clave: SITRAC, Fiat, clasismo, Córdoba, izquierdas, década del '70

Abstract: In this paper, we reconstruct the intervention of the of the left-wing groups in the SITRAC-SITRAM experience, a paradigm of clasista unionism in Argentina in the '70s. We specify which were the organizations that achieved militants in the new union leadership (POT, FAL, VC, PRT-ERP, PB-FAP and PCR), their main political and trade union orientations and their role in workers' politicization and in decisions of the new unions of Fiat.

Keywords: SITRAC, Fiat, clasismo, Córdoba, left-wing groups, '70s

Recibido: 7 febrero 2019 Aceptado: 19 marzo 2019

\section{Introducción}

El proceso que llevaron adelante los trabajadores de las plantas de Fiat Concord y Materfer de Córdoba durante 1970 y 1971 fue en su momento, y así quedó cristalizado en la historiografía, la experiencia paradigmática de lo que hasta hoy se conoce como el sindicalismo clasista en la Argentina. Durante poco más de un año y medio, estos desarrollaron una breve, pero pionera e intensa experiencia basada en la democracia sindical, la acción directa y la radicalización política, que los distinguió del resto de las corrientes del movimiento obrero argentino. Las nuevas direcciones del SITRAC (Sindicato de Trabajadores de Concord) y el SITRAM (Sindicato de Trabajadores de Materfer) transitaron una acelerada politización y fueron las primeras que en los '70 se autodefinieron bajo el título de "clasistas",

*CONICET - Universidad de Buenos Aires. Instituto de Historia Argentina y Americana “Dr. Emilio Ravignani”. Buenos Aires, Argentina. Este trabajo se sitúa como parte de la investigación para mi Tesis Doctoral en Historia en FFyL-UBA, que cuenta con el apoyo de una Beca CONICET. Rodolfo.laufer@yahoo.com.ar 
retomando los postulados de la lucha de clases y un concepto proveniente de la tradición de las izquierdas, pero en desuso durante las décadas precedentes. A partir de allí, el clasismo quedó configurado como una estrategia sindical específica y SITRAC-SITRAM se situó como el punto de referencia de una corriente que tuvo varias expresiones y llegó a adquirir una importante notoriedad en la argentina setentista.

Una vasta bibliografía de tipo académico, testimonial, político y periodístico ha abordado este proceso $^{1}$. Entre las investigaciones académicas, los escritos que sentaron la base para su interpretación fueron los de James Brennan y Mónica Gordillo, quienes reconstruyeron los principales hitos de la experiencia centrándose especialmente en los factores estructurales, históricos y culturales que le dieron asiento. Si bien estos hicieron referencia al rol de las izquierdas en la politización obrera en Fiat, no se encargaron de profundizar en este punto, interpretando a la experiencia esencialmente como un proceso que se inició con un carácter espontáneo, genuino y de base, más tarde desnaturalizado por una intervención externa y tutelar de las izquierdas. Trabajos más recientes, como los de Carlos Mignón y María Laura Ortiz, han vuelto sobre el tema ensayando nuevas perspectivas y señalando la importancia de los militantes de la izquierda en cuanto a la formación política y la radicalización ideológica de los nuevos dirigentes de Fiat. Sin embargo, aún permanece bajo un manto de sombra cuáles fueron exactamente las fuerzas políticas que tuvieron intervención en SITRAC-SITRAM, qué influencia concreta alcanzaron y cuáles fueron las orientaciones políticas y sindicales que plantearon.

Nuestra hipótesis es que la intervención de las izquierdas fue un factor consustancial de las prácticas y las definiciones de los nuevos sindicatos de Fiat prácticamente desde su inicio. Gran parte de los miembros de las nuevas Comisiones Directivas y cuerpos de delegados se ligaron de una u otra manera a estas organizaciones, las cuales les aportaron una serie de recursos teóricos, políticos y prácticos para encarar su nuevo rol sindical y contribuyeron a darle una dirección específica al proceso de politización que estaban atravesando los trabajadores de Fiat y su nuevo núcleo dirigente ${ }^{2}$. El sindicalismo clasista fue tomado e impulsado como estrategia sindical por una gran variedad de organizaciones de lo que se conoce como la nueva izquierda revolucionaria de los '70, tanto provenientes del tronco marxista como algunas de la izquierda peronista. Pero, a partir de esta común identificación con el clasismo, cada fuerza desarrolló una impronta particular, que se enlazaba con sus respectivas orientaciones políticas y estratégicas. En consecuencia, dentro del sindicalismo clasista convivieron distintas variantes, y comprender cuál o cuáles de estas fuerzas tuvieron intervención en SITRAC-SITRAM y qué rol cumplieron es un elemento que puede contribuir a echar luz sobre los rasgos específicos que tuvo este proceso y al mismo tiempo a complejizarlo, observando las distintas orientaciones que convivieron en su seno y las polémicas y cambios que lo

\footnotetext{
${ }^{1}$ Entre los trabajos principales, cabe mencionar: Beba Balvé et. al., Lucha de calles, lucha de clases, Buenos Aires, Ediciones RyR, 2006. Francisco Delich, Crisis y protesta social. Córdoba 1969-1973, Buenos Aires, Siglo XXI, 1974. Natalia Duval [Susana Fiorito], Los sindicatos clasistas: SiTraC (1970-1971), Buenos Aires, CEAL, 1988. Gregorio Flores, SITRAC-SITRAM. La lucha del Clasismo contra la Burocracia Sindical, Córdoba, Espartaco, 2004. James P. Brennan, El Cordobazo. Las guerras obreras en Córdoba 1955-1976, Buenos Aires, Sudamericana, 1996. Mónica Gordillo, Córdoba en los '60. La experiencia del sindicalismo combativo, Córdoba, REUN, 1996. James P. Brennan y Mónica Gordillo, Córdoba rebelde. El Cordobazo, el clasismo y la movilización social, La Plata, De la Campana, 2008. Héctor Schmucler et. al., El obrerismo de pasado y presente: Documento para un dossier no publicado sobre SiTraC-SiTraM, Córdoba, Eduvim, 2014. Carlos Mignon, Córdoba obrera. El sindicato en la fábrica 1968-1973, Buenos Aires, Imago Mundi, 2014. María Laura Ortiz, Violencia y represión. Los trabajadores clasistas en Córdoba, 1969-1976, Buenos Aires, Tesis de Doctorado inédita, FFyL-UBA, 2015.

2 El historiador y sociólogo Massimo Modonessi ha estudiado el rol de la militancia en lo que denomina "movimientos antagonistas", señalando que esta suele actuar como "el vector que orienta el movimiento, que le imprime una orientación política". Massimo Modonessi, El principio antagonista. Marxismo y acción política, México, Ítaca, 2016, p. 94. Para un estudio acerca del rol de los militantes de izquierda en la configuración de una "cultura política de protesta", ver Fernando Aiziczon, Cultura política, militantes y movilización: Neuquén durante los años '90, Buenos Aires, Prometeo, 2017.
} 
atravesaron. A su vez, puede aportar también a la comprensión de las experiencias posteriores del clasismo, asentadas sobre las lecciones dejadas por Fiat.

Recientemente fueron publicados los materiales que en 1971 y 1972 habían comenzado a redactar los miembros del grupo cordobés Pasado y Presente $(\mathrm{PyP})$ con vistas a la elaboración de un Dossier acerca de SITRAC-SITRAM, que finalmente nunca vio la luz $z^{3}$. Articulado en torno a la figura de José María Aricó, PyP se había conformado a partir de una ruptura del Partido Comunista (PC) a inicios de los '60 y ofició como un importante grupo político-intelectual ubicado dentro del espectro marxista4. Políticamente, en los términos del propio Aricó, en un principio estuvo ligado a la izquierda leninista y castrista, mientras que en su segunda etapa setentista se vinculó a la izquierda peronista, particularmente a Montoneros. A pesar de situarse a medio camino entre una fuente y una investigación, podemos afirmar que el trabajo de PyP fue el que más lejos llegó en cuanto al problema de la intervención de las izquierdas en Fiat. La pertenencia de sus miembros a este espacio político, su arraigo en la provincia mediterránea y la contemporaneidad con los hechos probablemente facilitaron su tarea. De este modo, a pesar de los problemas ocasionadas por el difícil acceso a muchos materiales partidarios y por las normas de clandestinidad militante de los actores, lograron identificar con una gran precisión a las principales fuerzas políticas que se esforzaron por influir en el proceso de Fiat. Veamos su juicio:

En un principio parece que los chinos [se refieren a Vanguardia Comunista] tuvieron mucha influencia, pero la perdieron por plantear una política aislacionista y muy dogmática. La agrupación " $1{ }^{\circ}$ de Mayo" [ligada al Partido Comunista Revolucionario] aparece como la más flexible, con mayor capacidad autocrítica y sin duda con mayor influencia. Los grupos trotskistas aparecieron como muy alejados. En cuanto a los grupos de acción directa, el ERP [Ejército Revolucionario del Pueblo] es el único importante que cada vez logra mayor adhesión de la gente. [...] Otro grupo con el que trabajan bien es con el Peronismo de Base. ${ }^{5}$

Este análisis coincide casi exactamente con el diagnóstico que fundamentaremos en este artículo sumándole una serie de agregados y precisiones. La propia perspectiva teórica y política de Pasado y Presente los desalentó de profundizar mucho más acerca de las características y alcances de esta intervención de las izquierdas, por lo que sobre este terreno es que intentaremos avanzar en este trabajo. Nuestro objetivo en este artículo es dar un primer paso imprescindible en este camino: puntualizar cuáles fueron exactamente las fuerzas políticas que participaron del proceso, qué fuerza propia obtuvieron a nivel de las direcciones de Fiat y cuáles fueron algunos de los aspectos fundamentales de sus orientaciones político-sindicales que influyeron en las definiciones de SITRAC-SITRAM. Por razones de extensión, y debido a que la base documental y testimonial es mucho más amplia que para el caso de Materfer, nos concentraremos en el caso del SITRAC.

Para esta reconstrucción y análisis nos basamos en el relevamiento de una gran variedad de materiales: el Archivo del SITRAC; documentos, volantes, revistas y periódicos de las distintas fuerzas políticas de la izquierda marxista y peronista ${ }^{6}$; testimonios de dirigentes del SITRAC recogidos por

\footnotetext{
${ }^{3}$ Schmucler et. al., op cit.

${ }^{4}$ Sobre PyP, ver, entre otros, José Aricó, La cola del diablo. Itinerario de Gramsci en América Latina, Buenos Aires, Puntosur, 1988. Raúl Burgos, Los gramscianos argentinos. Cultura y politica en la experiencia de Pasado y Presente, Buenos Aires, Siglo XXI, 2004. Horacio Crespo, "En torno a Cuadernos de Pasado y Presente, 1968-1983", en Claudia Hilb (comp.), El político y el científico. En sayos en bomenaje a Juan Carlos Portantiero, Buenos Aires, Siglo XXI, 2009.

5 Pasado y Presente, en Schmucler et. al., op cit., pp. 144-145.

${ }^{6}$ En gran medida este trabajo es posible debido a la gran labor de recuperación de documentos de las izquierdas realizado en los últimos años por instituciones y grupos como el Centro de Documentación e Investigación de la Cultura de Izquierdas
} 
nuestra cuenta o por colegas, publicados o conservados en archivos de historia oral; testimonios de militantes y dirigentes de las izquierdas; y diarios y revistas de Córdoba y nacionales. A su vez, nos valimos de la amplia bibliografía acerca del proceso de SITRAC-SITRAM y acerca de las distintas fuerzas políticas de las izquierdas.

El cruce de los distintos materiales nos permite establecer una primera delimitación, que adelantamos para fundamentar los alcances de nuestra exposición. En un primer grupo ubicamos a las organizaciones que no solo intervinieron desde afuera de la fábrica, sino que lograron incorporar o trabar relaciones con algunos miembros de la dirigencia de Concord. Sin presentarlos necesariamente en orden de importancia, estas fueron: el Partido Obrero Trotskista (POT), las Fuerzas Armadas de Liberación (FAL) ${ }^{7}$, Vanguardia Comunista (VC), el Partido Revolucionario de los Trabajadores-Ejército Revolucionario del Pueblo (PRT-ERP), el Peronismo de Base-Fuerzas Armadas Peronistas (PB-FAP) y el Partido Comunista Revolucionario (PCR). Como se puede apreciar, salvo por las dos primeras, coincide con el citado juicio de Pasado y Presente. Como es lógico, la vinculación directa con algún miembro de la dirección sindical posibilitó a estas organizaciones influir en mayor grado sobre las acciones y definiciones sindicales. En un segundo grupo ubicamos a otras fuerzas que también acompañaron el proceso, participaron en sus iniciativas e intentaron influir en sus orientaciones, pero que no parecen haber logrado una fuerza interna. Entre ellas, cabe mencionar a El Obrero, Política Obrera (PO), el Partido Revolucionario de los Trabajadores-La Verdad (PRT-LV) y Espartaco, junto con otros grupos menores. En un tercer grupo correspondería incluir al Partido Comunista, que había tenido militancia previamente en Concord, pero, como señalaremos, su distanciamiento con los nuevos sindicatos clasistas será muy marcado, a pesar de lo cual también participó en muchas de sus iniciativas y ofreció sus orientaciones.

En este trabajo nos abocaremos al análisis del primer grupo de fuerzas, aunque también utilizamos los materiales de las demás para trazar el panorama de las izquierdas en Fiat. La gran cantidad de organizaciones de que se trata nos obliga a ofrecer solo algunos lineamientos generales de la intervención de cada una, opción que tomamos deliberadamente en pos de ofrecer un primer panorama global que siente las bases para futuras indagaciones que profundicen en cada fuerza.

Por otra parte, hubo también una serie de personalidades que, ubicadas en el espectro de las izquierdas, pero sin encuadramiento partidario, jugaron un rol destacado como parte misma de la experiencia. Nos referimos en particular a los doctores Alfredo Curutchet y Martín Federico, abogados de SITRAC-SITRAM, a Susana Fiorito, secretaria del SITRAC, y a Pedro Milesi, sobre los cuales ofreceremos también algunos elementos acerca de sus ubicaciones políticas y sus actuaciones.

Finalmente, cabe señalar que, en los años posteriores a la disolución de SITRAC-SITRAM, muchas de estas fuerzas políticas, así como muchos protagonistas, realizaron balances críticos y autocríticos de la experiencia de Fiat, y no pocas organizaciones hicieron importantes cambios en sus propias orientaciones sindicales. Esta cuestión, de por sí fundamental para el estudio de las experiencias posteriores del clasismo, escapa a este trabajo, en el cual nos circunscribiremos centralmente a lo que cada actor sostuvo, impulsó y realizó durante el transcurso del proceso de SITRAC-SITRAM.

\section{El nuevo SITRAC}

La experiencia de SITRAC-SITRAM se desarrolló entre marzo de 1970 y octubre de 1971. Desde 1966, la Argentina se hallaba bajo la dictadura de la autodenominada "Revolución Argentina", que se había propuesto ponerle fin a la crisis de hegemonía abierta desde el derrocamiento del gobierno de Juan

(CEDINCI), al Centro de documentación de las organizaciones político-militares argentinas "El Topo Blindado", "Ruinas Digitales" y al Archivo de las Izquierdas Rosario.

${ }^{7}$ La sigla FAL hace referencia a tres denominaciones diferentes: Fuerzas Armadas de Liberación, Frente Argentino de Liberación y Fuerzas Argentinas de Liberación. Para simplificar, en este artículo utilizaremos la primera. 
Domingo Perón once años atrás. Sin embargo, en el marco de un período de ascenso revolucionario a nivel mundial, la política del gobierno de Juan Carlos Onganía terminó por incentivar una radicalización política general, que en el movimiento obrero se expresó en el crecimiento de distintas expresiones antiburocráticas y combativas. El 29 de mayo de 1969, la rebelión obrera, estudiantil y popular conocida como el "Cordobazo" hirió de muerte al proyecto dictatorial, abriendo un período atravesado por una intensa pugna entre distintas fuerzas sociales y proyectos políticos.

Desde mediados de los años '60, a partir de la dura derrota de la gran lucha de Fiat de $1965^{8}$, los trabajadores de las plantas de Concord y Materfer que el monopolio italiano Fiat poseía en Córdoba tenían sindicatos de fábrica "amarillos", completamente subordinados a la empresa y vaciados de participación obrera. En Concord, donde trabajaban más de 2.500 obreros, el SITRAC que conducía Jorge Lozano solo tenía una pequeña minoría de afiliados. Sobre esta base, la patronal había logrado ir avanzando sobre las condiciones salariales y de trabajo según su propia conveniencia y prácticamente sin resistencias.

El punto de quiebre en esta situación se produjo el 23 de marzo de 1970. El rechazo contenido en las bases de Concord estalló finalmente durante una masiva asamblea motivada por la discusión de un nuevo convenio colectivo de trabajo. Los trabajadores resolvieron la expulsión de la Comisión Directiva del SITRAC y se conformó una Comisión Provisoria para llevar adelante las gestiones de la destitución y la convocatoria a nuevas elecciones sindicales. Durante los siguientes dos meses, al compás de estas tratativas y de las múltiples trabas encontradas en el camino por parte de la Fiat y el Gobierno, se fue configurando un nuevo grupo dirigente que articuló a algunos de los miembros de la Comisión Provisoria, como Carlos Masera, Santos Torres y Rafael Clavero, a un grupo de delegados antilozanistas, Domingo Bizzi, Alfio Taverna y Carlos Monjes, y a otros trabajadores que se fueron destacando por su politización y combatividad, como Gregorio Flores, José Páez y Mario Jiménez.

El 14 de mayo, cansados de dilaciones, y asesorados por su nuevo abogado, Alfredo Curutchet, los obreros de Concord ocuparon la planta y lograron la destitución de la Comisión Directiva. La toma fue un momento clave que redefinió la situación: si hasta entonces los trabajadores se oponían esencialmente a Lozano, con esta medida pasaban a chocar directamente contra la patronal y contra el Estado'. Dos meses después se concretarían las elecciones que consagraron a la nueva dirección, encabezada por Carlos Masera y Domingo Bizzi. Tras ello, se procedió también a la elección del nuevo cuerpo de delegados, que, con 95 integrantes, cumpliría un rol de dirección codo a codo con los miembros de la Comisión Directiva.

A principios de junio se inició un proceso paralelo en la planta de Materfer. Los obreros tomaron la fábrica y en asamblea destituyeron a las autoridades sindicales encabezadas por Hugo Casanova y designaron una Comisión Provisoria. En agosto, también allí se realizaron elecciones, quedando el nuevo SITRAM encabezado por Florencio Díaz y Tomás Ignacio Villalba, junto a otros delegados y dirigentes destacados como Eduardo Castelo, Raúl Suffi, Dante Suárez, José Pagnanini y Víctor Frontera. Nacía así la dupla "SITRAC-SITRAM".

La nueva experiencia rápidamente se distinguió en el escenario sindical. Desde el inicio estuvo marcada por una intensa democracia sindical, con constantes asambleas y reuniones de delegados, y una estrecha ligazón de los dirigentes con las bases. Junto con esto, los nuevos sindicatos llevaron a la práctica medidas de lucha sumamente radicalizadas, como tomas fabriles con rehenes, movilizaciones callejeras

\footnotetext{
8 “Informe preliminar sobre el conflicto de Fiat", Pasado y Presente, No 9, abril-septiembre 1965. Flores, 2004, op. cit., pp. 114-125.

9 El comunicado difundido por la Comisión Provisoria expresaba claramente el cambio, sosteniendo que "el objetivo fundamental que orienta nuestra lucha es la defenestración de una dirección sindical traidora enquistada actualmente en el SITRAC en virtud del fraude tolerado por los funcionarios de trabajo y orientado por la empresa Fiat Concord". Diario Córdoba, 15-5-1970.
} 
enfrentando la represión y ocupaciones de barrios ${ }^{10}$. Sobre esta base, los trabajadores de Fiat fueron estableciendo también una nueva relación de fuerzas en las plantas, desafiando el control empresarial sobre el proceso productivo y enarbolando reivindicaciones salariales y de condiciones de trabajo como el fin del premio a la producción, la insalubridad, los ritmos de trabajo y las calificaciones.

Los nuevos sindicatos, a su vez, se plantearon una ubicación autónoma respecto de los nucleamientos sindicales existentes en el movimiento obrero de Córdoba: el peronismo ortodoxo, el peronismo legalista y los gremios independientes ${ }^{11}$. Los dirigentes de Fiat iniciaron una escalada de enfrentamientos con la CGT nacional encabezada por José Rucci, y especialmente con la dirección de la CGT local, a la que calificaban como una "burocracia sindical traidora" 12 , llegando a tomar su sede durante una manifestación el 12 de noviembre de 1970 y llamando en varias ocasiones a realizar medidas de lucha por separado de las convocadas por la central. El choque se produjo no solo con los sectores del sindicalismo peronista, sino también, aunque en ocasiones más matizado, con los gremios independientes que orientaba Tosco, al que en general se calificaba como reformista y demasiado alineado con el PC ${ }^{13}$. A inicios de 1971, SITRAC-SITRAM se autodefinieron explícitamente como sindicatos clasistas $^{14}$ y comenzaron a profundizar sus vínculos directamente con las bases de otros gremios, entre

${ }^{10}$ Concord fue ocupada dos veces, en mayo de 1970 para lograr la destitución de Lozano, y en enero de 1971 contra el despido de siete dirigentes del SITRAC. A su vez, los sindicatos de Fiat protagonizaron el "Ferreyrazo" y el "Viborazo", o Segundo Cordobazo, de marzo de 1971. Ver Balvé et. al., op. cit.

${ }^{11} \mathrm{El}$ peronismo ortodoxo estaba liderado por Alejo Simó de la UOM (metalúrgicos) y profesaba un cerrado verticalismo y la lealtad a Perón; el peronismo legalista, más vinculado al vandorismo y luego al peronismo combativo, y proclive a alianzas con sectores no peronistas, en ese momento se referenciaba en Elpidio Torres del SMATA (mecánicos) y Atilio López de la UTA (colectiveros); y los gremios independientes, encabezados por Agustín Tosco de Luz y Fuerza (electricistas), estaban integrados por gremios con conducciones radicales y de izquierda, entre ellas el Movimiento de Unidad y Coordinación Sindical (MUCS) que auspiciaba el Partido Comunista (PC).

12 Es necesario tener presente que durante la experiencia de SITRAC-SITRAM la CGT Córdoba pasó por tres momentos. Desde marzo a septiembre de 1970 estuvo bajo la dirección de Elpidio Torres, del SMATA, en base a un acuerdo entre legalistas y ortodoxos. De septiembre de 1970 a marzo de 1971, tras la renuncia de Torres, la central estuvo acéfala, pero bajo la égida del sector ortodoxo. En marzo de 1971 se conformó una Comisión de Lucha que fue la base para la normalización de la CGT cordobesa en abril, ahora en un acuerdo de legalistas e independientes y encabezada por Atilio López y Agustín Tosco.

${ }^{13}$ Como señalan Brennan y Gordillo, la desconfianza fue mutua: "Los recelos de Tosco provenían más de su escasa comprensión de lo que estaba sucediendo en Ferreyra que de genuinas diferencias políticas. Desde el momento en que el gobierno asumió el control de Luz y Fuerza a principios de febrero hasta el restablecimiento de su personería gremial en septiembre de 1971, Tosco y la conducción sindical trabajaron ocultos. En consecuencia, por lo que se refiere al grueso de la experiencia clasista en Fiat, Tosco solo recibía informaciones por intermediarios" (2008: 130). Lo más probable es que estos intermediarios fueran efectivamente los miembros del PC de Córdoba. Según los materiales partidarios, estos habían tenido militantes en Concord desde sus orígenes, pero en 1970 ya no contaban con ninguno en la planta. El desencuentro entre el PC y los dirigentes de Fiat alcanzó niveles virulentos, y el Partido Comunista sostuvo que estos no eran clasistas sino "ultraizquierdistas" " "aventureros". Aníbal Córdoba, El "Cordobazo". Apuntes de un combatiente, Buenos Aires, Anteo, 1971. Rubén Vianoli [Jorge Canelles], ¿Clasismo o aventurerismo? SITRAC-SITRAM. Experiencias y enseñanzas, Buenos Aires, Anteo, 1972. Jorge Bergstein, El "Cordobazo". Memorias, testimonios, reflexiones, Buenos Aires, Cartago, 1987. La Mulita, Periódico de los trabajadores comunistas de Fiat, No 9, 9-1971, Archivo de SITRAC/Subarchivo 18/Ficha 9.

14 Según nuestro relevamiento, la autoidentificación de SITRAC-SITRAM como sindicatos clasistas se produjo recién en los primeros meses de 1971, a casi un año de iniciado el proceso. En el Periódico del SITRAC No 1, publicado el 13 de enero, ya se definían como "una dirección sindical clasista y combativa". SITRAC, Boletín del Sindicato Trabajadores Concord, No 1, 13-1-71, p. 1, Archivo de SITRAC/Subarchivo 1/Ficha 1. Pero en donde apareció más clara y explícitamente esta identificación fue en un comunicado dado a conocer el 8 de febrero, donde, bajo la firma de los principales directivos del SITRAC (Masera y Bizzi) y del SITRAM (Díaz, Villalba y Pagnanini), se definían como un "sindicalismo clasista y de bases, practicado en un marco de auténtica democracia obrera". "SITRAC y SITRAM. Al pueblo de Córdoba", Comunicado de SITRAC-SITRAM, 8-2-1971, Archivo de SITRAC/Subarchivo 13/Ficha 9. En marzo de ese año, la revista Panorama titulaba una entrevista a Masera y Díaz: "SITRACSITRAM: Somos clasistas". Allí, ambos dirigentes llamaban a "construir organizaciones clasistas e independientes políticamente de la burguesía" y señalaban que "en el campo gremial nuestra lucha pretende presentar una alternativa claramente socialista". Revista Panorama, No 202, 9 al 15-3-1971. 
ellos el SMATA, Perkins y Empleados Públicos. El intento por extender el sindicalismo clasista no se restringió a Córdoba, y SITRAC-SITRAM auspiciaron en agosto de 1971 un "Congreso Nacional de sindicatos combativos, agrupaciones clasistas y obreros revolucionarios" al cual llegaron delegaciones de todo el país ${ }^{15}$.

Al calor de la situación general y de las luchas emprendidas, la politización de SITRAC-SITRAM fue en pleno ascenso. En los escritos y discursos de sus dirigentes empezaron a repetirse los planteos "antidictatoriales, antipatronales y antiburocráticos", así como las consignas por la liberación nacional y social -O "social y nacional", según el escrito-, el socialismo y el lema "Ni golpe ni elección, revolución"16. En agosto de 1970, el referente del SITRAC Gregorio Flores se definió públicamente por el socialismo, motivando un intenso debate sobre la política, el capitalismo y el socialismo en el cuerpo de delegados de Concord ${ }^{17}$. En mayo de 1971, SITRAC-SITRAM presentó en el Plenario Nacional de Gremios Combativos un proyecto de programa que se planteaba como las "bases programáticas del movimiento obrero clasista" y realizaba una serie de caracterizaciones acerca del sindicalismo, la Argentina y el tipo de revolución postulada ${ }^{18}$. La politización de los dirigentes corrió pareja con la apertura hacia el movimiento estudiantil y las organizaciones de la nueva izquierda: el 3 de julio de 1970 se votó que todas las "agrupaciones hermanas" pudieran hablar en los actos y asambleas en puerta de fábrica, se fueron conformando Comisiones de Solidaridad en las que participaban las distintas fuerzas y el vínculo prácticamente se institucionalizó mediante la costumbre de convocar reuniones abiertas para escuchar todas las posiciones antes de cada decisión importante. A su vez, el SITRAC se solidarizó con los estudiantes de la Facultad de Ingeniería reprimidos en mayo de 1970 y se comprometió con la lucha por la libertad de los presos políticos, tanto los propios como los de las distintas organizaciones revolucionarias, y en varias ocasiones reivindicó las acciones de las organizaciones armadas ${ }^{19}$.

La proyección nacional que estaban logrando SITRAC-SITRAM, su prédica contra el Gran Acuerdo Nacional (GAN) que impulsaba la nueva cabeza de la "Revolución Argentina", Alejandro A. Lanusse, su desafío al control empresarial del proceso productivo, su articulación con las organizaciones de la nueva izquierda y su choque frontal contra las corrientes hegemónicas del sindicalismo, llevaron a que finalmente la dictadura decidiera aplastar la experiencia. El 26 de octubre de 1971 se inició la escalada: el Ministerio de Trabajo canceló las inscripciones y personerías gremiales de ambos sindicatos, al tiempo que la gendarmería ocupaba las plantas, la policía provincial tomaba las sedes sindicales y la empresa procedía a despedir a 259 trabajadores, entre ellos la totalidad de las Comisiones Directivas y Cuerpos de Delegados y a numerosos activistas. A muchos de estos además se les dictó orden de captura, deteniéndolos u

15 El "Plan de Lucha aprobado en el Plenario convocado por SITRAC-SITRAM el día 28 de agosto de 1971" llamaba a "crear el verdadero sindicalismo clasista y revolucionario", planteaba la consigna "Ni golpe ni elección, revolución" y se pronunciaba "por la destrucción definitiva del capitalismo, y por ende la de su fase superior, el imperialismo, y por la construcción del socialismo". Archivo de SITRAC/Subarchivo 7/Ficha 6b. Ver la convocatoria, los asistentes y otros documentos del Congreso en Archivo de SITRAC/Subarchivo 7/Fichas 1-5.

16 Ya en diciembre de 1970, el "Programa general de lucha para el pueblo trabajador de Córdoba" presentado por el SITRAC se pronunciaba en contra "De la política entreguista y represiva de la dictadura. De la patronal imperialista monopolista y sus planes de superexplotación. De la burocracia sindical traidora al servicio de la dictadura y la patronal", y culminaba convocando a "la liberación nacional y social de nuestra patria”. En SITRAC Boletín..., op. cit., p. 4.

17 Ver el relato del "Goyo" en Flores, op. cit., pp. 171-172. Gregorio Flores, Lecciones de batalla. Una historia personal de los '70, Buenos Aires, Ediciones RyR, 2006, pp. 111-112.

18 "Programa de SITRAC-SITRAM", Ponencia de SiTraC-SiTraM al Plenario de Gremios Combativos, Archivo de SITRAC/Subarchivo 7/Ficha 1. El programa presentado abrió una intensa polémica en todo el arco de las izquierdas.

${ }^{19}$ En el primer número del Periódico del SITRAC fueron publicados mensajes enviados por Montoneros, el ERP y las FAL. SITRAC Boletín..., op. cit., pp. 4-5. Y el 3 de marzo de 1971, tras un acto de la CGT, los trabajadores de Fiat marcharon a la Cárcel de Encausados, donde escucharon desde detrás de las rejas las palabras de Ignacio Vélez de Montoneros, Domingo Menna del PRT-ERP y Sergio Ortiz de VC. Américo Soto, Vidas y Luchas de Vanguardia Comunista, Buenos Aires, Nuevos Tiempos, 2010, p. 128. 
obligándolos a pasar a la clandestinidad. Los intentos de resistencia fueron vanos frente al descomunal operativo, que tomó a los dirigentes de Fiat en gran medida desprevenidos y sin una preparación suficiente. Durante los meses siguientes el "SITRAC-SITRAM en la resistencia" pasó a centrarse, sin éxito, en la lucha por la reincorporación de los despedidos y por la recuperación de la personería de los sindicatos. Será recién con el triunfó la Lista Marrón encabezada por René Salamanca en el SMATA cordobés en abril de 1972, cuando se abriría una nueva perspectiva: la lucha por la integración de Concord y Materfer al sindicato mecánico.

\section{La intervención de las izquierdas en el proceso}

La intempestiva aparición de los nuevos SITRAC y SITRAM, sus métodos asamblearios y de acción directa y su distanciamiento respecto de las corrientes tradicionales del sindicalismo cordobés, atrajeron inmediatamente a las distintas organizaciones de la nueva izquierda presentes en Córdoba. Rápidamente, estas enviaron a sus militantes obreros, estudiantiles, intelectuales y partidarios a establecer contacto con los nuevos dirigentes y delegados de Fiat, que los acogieron con una receptividad poco usual en el ámbito sindical.

En los testimonios de los protagonistas aparece claramente la vinculación entre la relación con los militantes de las izquierdas y los avances en sus definiciones ideológicas y sindicales:

Al día siguiente de haber triunfado con la toma, llegaron varios intelectuales de izquierda para saber qué pasaba. Los obreros estábamos en pañales y ellos tenían capacidad de asesoramiento, por lo que empezó a haber un contacto permanente con ellos. Alguien de los que se acercó mencionó el clasismo. Yo tenía un dilema, venía del peronismo y había militado cuando trabajaba en IAME, pero con la traición de la burocracia sindical buscaba una alternativa que no sabía cuál era, porque no la había. Cuando escuché la palabra clasismo me pareció que se ajustaba a lo que pensaba. Era defender una clase, me daba cuenta de que la sociedad se dividía en clases. Un día un periodista me preguntó en la televisión si éramos trotskistas o marxistas, y yo respondí "No, nosotros somos clasistas", sin tener otra claridad. ${ }^{20}$

Se acercaron muchos estudiantes, que hicieron su aporte intelectual, a veces interesados políticamente, pero no interesaba, lo que interesaba era la cuestión ideológica que iba ganando en los compañeros. Y un poco, fundamentalmente Curutchet, pero un poco también el aporte de los estudiantes, fuimos entendiendo cómo estaba conformada la sociedad, entender que la sociedad era una permanente lucha de clases, y empezamos a entender que no puede ser una propiedad privada los medios de producción porque la riqueza la generan quienes trabajan, y una serie de cosas que nos animábamos o nos interesábamos por leer. Entonces fue generando en los compañeros, y yo y muchos compañeros, esa nueva incursión ideológica al socialismo. Es por ello que adoptamos la posición clasista, porque entendíamos que la lucha de clases existía, entonces no podía ser de otra manera que, al asumir la defensa de la clase trabajadora, la posición sea clasista, como es clasista los que dirigen hoy la sociedad. ${ }^{21}$

Todos los testimonios coinciden en que el abogado Alfredo "Cuqui" Curutchet, su joven asesor legal, tuvo un papel destacado en todo el proceso. Su llegada fue prácticamente casual, pero a partir de

\footnotetext{
${ }^{20}$ Entrevista a Carlos Masera, en Revista Los '70, No 8, Buenos Aires, 1997.

${ }^{21}$ Entrevista a Domingo Bizzi, en Área de Historia Oral del Archivo Provincial de la Memoria de Córdoba, 6-11-2009.
} 
entonces tuvo una activa participación en las luchas y definiciones de los nuevos sindicatos de Fiat. Lo que se conoce menos es acerca de sus antecedentes y su ubicación política. Según el relato de su hermana, su padre era un comerciante acomodado, de ideas socialistas, votante de los radicales y muy crítico del peronismo ${ }^{22}$. Alfredo había hecho el Liceo Militar en la capital provincial y estudiado derecho en la Universidad de Córdoba, donde hizo sus primeras incursiones en la política estudiantil. Roberto Ferrero, quien cursó la carrera de derecho junto al "Cuqui", afirma que en los '60 "no había manifestación estudiantil o popular, ocupación de Facultad o enfrentamiento con el Escuadrón de Caballería de la policía provincial donde él no estuviera presente", y agrega:

Políticamente, militaba en la "Unión Reformista Universitaria" (URU) de la Facultad de Derecho, agrupación que dirigía Abraham Kozak ("el ruso" o "el loco"). Teníamos una posición socialista cubanista, independiente, aunque había algunos que pertenecían orgánicamente a algún partido de izquierda. ${ }^{23}$

Tras recibirse en 1965, Curutchet se dedicó a la defensa de presos políticos, gremiales y estudiantiles y se fue especializando en el derecho laboral, asesorando a agrupaciones sindicales de base, a sindicatos como Luz y Fuerza y Pasteleros y a la seccional cordobesa de la CGT de los Argentinos, siendo detenido en varias oportunidades ${ }^{24}$. Domingo Bizzi destaca con claridad la importancia de la figura de Curutchet en los inicios del nuevo SITRAC: "Su asesoramiento y el de otros intelectuales que se acercaron a nosotros, no se restringía a lo legal. Ellos nos fueron apuntando cómo el sindicato tenía que ser el primer escalón para la toma de conciencia de los trabajadores" 25 . Y el propio abogado describía su rol en los siguientes términos:

se juega como un compañero más en la lucha en igualdad de condiciones, en un marco de democracia de bases participamos todos por igual en la elaboración de la línea gremial, política, en el asesoramiento técnico inclusive, porque yo, por ejemplo, no actúo jurídicamente de manera exclusivamente profesional y al margen de los criterios que se mueven en la dirección y la base del gremio, sino que está subordinado a lo político. ${ }^{26}$

Específicamente en 1970, no está claro si Curutchet estaba vinculado con alguna organización política en concreto, pero sí que ya tenía una clara formación marxista y se ubicaba dentro del espacio de la nueva izquierda revolucionaria, muy crítico del PC y del trotskismo. Varios testimonios le atribuyen cierta afinidad inicial con el $\mathrm{PCR}^{27}$, pero ya en 1971 comienza a aparecer más clara una relación directa con el PRT-ERP28.

22 Entrevista del autor a María del Carmen Curutchet, Córdoba, 24-11-18.

23 Roberto Ferrero, "El Cuqui Curutchet que conocí”, inédito, 2018.

${ }^{24}$ Entrevista de Pasado y Presente a Alfredo Curutchet, 1971, en Schmucler et. al., op. cit., pp. 312-314. Esteban Rafael Ortiz, Los abogados del pueblo. El derecho contra el poder. El caso del Dr. Alfredo "Cuqui" Curutchet (1969-1974), Narvaja, 2007.

${ }^{25}$ Entrevista a Domingo Bizzi, en Susana Roitman et. al., El torno y la molotov. Relatos e imágenes de la Córdoba obrera 60-70, Córdoba, Universitas, 2010, p. 82.

${ }^{26}$ Entrevista de Pasado y Presente a Alfredo Curutchet, op. cit., p. 315

${ }^{27}$ En su momento, Pasado y Presente consideraba que los abogados de SITRAC-SITRAM estaban "cerca del PCR". PyP, en Schmucler et. al., op. cit., p. 141. De hecho, el socio del estudio de Curutchet, Humberto Marioni, militaba en dicho partido.

28 Abel Bohoslavsky, miembro del PRT de Córdoba por esos años, entre otros militantes partidarios, confirma esta relación. Abel Bohoslavsky, "Biografías y relatos insurgentes. La historia del PRT en la memoria de Abel Bohoslavsky", Sísifo, Año I, No 1, SITOSPLAD, Buenos Aires, 2011, p. 131. Y el propio periódico partidario, a un año de su asesinato por la Triple A en septiembre de 1974, publicó una nota en su memoria mencionándolo como "militante de nuestro Partido". El Combatiente, Órgano del Partido Revolucionario de los Trabajadores, No 182, 10-9-1975, p. 6. 
Junto con Curutchet se incorporaría posteriormente, también como abogado, el Dr. Martín Federico. Hijo de quien fuera intendente municipal de la ciudad de Córdoba durante los primeros gobiernos de Perón, Federico militaba en el peronismo revolucionario desde la década del '60 y por esos años era parte de las Unidades Básicas Revolucionarias de Córdoba junto a Aldo Bosarelli, vinculadas al Frente Revolucionario Peronista (FRP) que dirigía el salteño Armando Jaime ${ }^{29}$. El FRP combinaba la identidad peronista y una base teórico-programático con muchos elementos del marxismo, y reivindicaba el sindicalismo clasista ${ }^{30}$. Fue la fuerza política que en 1973 conduciría la experiencia de la llamada "CGT clasista de Salta" 31.

El único partido de la izquierda marxista que parece haber tenido una presencia militante en Concord previa a 1970 es el Partido Obrero (Trotskista) ${ }^{32}$. Alfio Taverna había entrado a Fiat en 1963, siendo elegido como delegado de Tratamientos Térmicos, una de las secciones más insalubres ${ }^{33}$. A partir de eso se sumó al PO (T) y comenzó a enfrentar a Lozano, exigiendo, junto con otros delegados y trabajadores, la realización de asambleas generales. Cuando finalmente se produjo la asamblea que destituyó a la CD del SITRAC, Taverna estaba internado por problemas de salud y no pudo participar, pero luego se sumó al proceso, quedando como vocal en la nueva Comisión Directiva sindical.

Si bien el PO (T) participó de la experiencia del nuevo SITRAC y en el periódico partidario se comenzó caracterizando a las nuevas direcciones de Fiat como la expresión de "una corriente muy combativa y avanzada políticamente de la clase obrera cordobesa" 34 , no parece que la estrategia sindical del partido haya tenido una influencia significativa sobre sus definiciones. El PO (T) hacía eje en la necesidad de unificar a los sindicatos de Fiat y el SMATA en un Sindicato Único de la Industria Metalúrgica, realizaba una fuerte reivindicación de las corrientes sindicales que encabezaban Tosco y Atilio López, y pugnaba por que la CGT local tomara como base de su acción los programas de La Falda y Huerta Grande, en el camino de un "Partido Obrero basado en los sindicatos" y un "Gobierno Popular basado en los sindicatos", todas cuestiones que no encontramos entre las orientaciones adoptadas por SITRAC-SITRAM. De este modo, el PO (T) pronto se transformó en un duro crítico de lo que caracterizaba como posiciones "sectarias" y "aislacionistas" respecto al resto del movimiento obrero cordobés y la pretensión de utilizar al sindicato "como si fuera un instrumento de acción política" sobrepasando sus funciones específicas ${ }^{35}$.

Carlos Masera venía de una familia peronista y él mismo siempre se había filiado en dicha identidad política. Antes de ingresar a Fiat había pasado por la Fábrica Militar de Aviones (FMA) y por la Kaiser, donde había actuado brevemente como subdelegado y trabado unos primeros contactos con militantes del PC y del PO (T), que le aportaron sus primeros conocimientos del marxismo ${ }^{36}$. Su entrada a la Fiat se produjo en 1964, y tras la dura derrota de la lucha de 1965 se alejó del sindicato, ahora en manos de Lozano. Aun así, sus inquietudes políticas no cesaron, y las compartía con su amigo "el petiso" Páez, con

${ }^{29}$ Entrevista del autor a Manuel Justo Gaggero, Buenos Aires, 1-2-2019. Manuel Justo Gaggero, “Morir en Buenos Aires”, en Página 12, 10-1-2006. Roberto Baschetti, Militantes del peronismo revolucionario uno $x$ uno, en http://www.robertobaschetti.com/biografia/f/22.html.

30 Ver Rubén Correa y Carlos Holmquist, "Estudios sobre el peronismo revolucionario: el FRP en Salta, 1972-1975”, en X Jornadas Interescuelas de Historia, Catamarca, UNCA, 2011. Entrevista del autor a Armando Jaime, Salta, 3-10-2016. Roberto Baschetti, Militantes del peronismo revolucionario uno x uno, en http://www.robertobaschetti.com/biografia/b/202.html.

31 Ver Rodolfo Laufer, "La CGT clasista de Salta, 1973", Documentos y Comunicaciones 2017, PIMSA, Buenos Aires, pre-edición digital. http://www.pimsa.secyt.gov.ar/novedades/La CGT clasista de Salta 1973.pdf.

32 Sobre el PO (T), ver Guillermo Almeyra, Militante crítico: una vida de lucha sin concesiones, Buenos Aires, Continente, 2013. Osvaldo Coggiola, Historia del trotskismo en Argentina y América Latina, Buenos Aires, Ediciones RyR, 2006. Héctor Menéndez, "El fracaso de la dirección obrera y las causas de la derrota después del Cordobazo", Ponencia en Jornadas "A 40 años del Cordobazo", Córdoba, mayo 2009. Roberto Ferrero, "La implantación del trotskismo en Córdoba", en En la huella de Abelardo. Ensayos de izquierda nacional, Córdoba, Ediciones del CEPEN, 2013. Almeyra, Menéndez y Ferrero fueron dirigentes del PO (T) de Córdoba.

33 Entrevista del autor a Alfio Taverna, Vía telefónica: Buenos Aires-Santiago del Estero, 17-1-2019.

34 Voz Proletaria. Órgano del Partido Obrero (Trotskista), No 663, 13-9-1970.

35 Voz Proletaria..., No 671, 5-6-1971; No 677, 17-7-1971; No 693, 6-11-1971.

36 Entrevista del autor a Carlos Masera, Córdoba, 20-11-18. 
quien trabajaban juntos en un pequeño taller hogareño. Su salto a la palestra se produjo en la asamblea de marzo, en donde fue quien propuso la conformación de la Comisión Provisoria, quedando como uno de sus integrantes y luego como Secretario General del SITRAC.

En el curso de este proceso Masera tomó contacto con muchas organizaciones, pero con quienes estableció una relación fue con las Fuerzas Armadas de Liberación ${ }^{37}$, una peculiar organización políticomilitar (OPM) que actuó brevemente, entre 1970 y 1972. En general provenientes de distintos grupos marxistas o filo-peronistas, sus miembros se propusieron dedicarse estrictamente a la construcción del aparato militar urbano que consideraban necesitaba la revolución, realizando acciones de acumulación material y de propaganda armada. En Córdoba habían conformado dos células a fines de 1969, con militantes provenientes de Buenos Aires e incorporaciones locales, bajo la dirección de "Chiche", quien había militado en el PC y en el PCR. Según Masera, su atracción por las FAL se debió a que eran una fuerza de izquierda y revolucionaria, pero que "no agredía al peronismo" sino que "trataba de persuadir". Efectivamente, el culto a la acción militar por encima de las definiciones políticas e ideológicas permitía a las FAL albergar las más variadas posiciones políticas, pero también fijaba sus limitaciones para orientar un proceso como el de Fiat.

La ausencia de un órgano de difusión hace difícil reconstruir sus posiciones políticas coyunturales o sus orientaciones sindicales, que por otra parte parecen haber sido escasas ${ }^{38}$. En ese sentido, es probable que su aporte a Masera no haya ido más allá de cierta formación ideológica, y fundamentalmente de protección frente a la represión, y que en su labor sindical este se guiara en lo principal en base a sus propios criterios personales. Lo que sí realizaron las FAL fueron varias acciones armadas en relación con SITRAC-SITRAM, como el incendio de sus oficinas o la toma del domicilio de su director comercial, dejando siempre comunicados de solidaridad con los obreros. Y sumaron también a otros obreros de Fiat, como los hermanos Ramón y Daniel Ortega y Omar Ludueña. Masera terminó por desvincularse de las FAL hacia mediados de 1971, al mismo tiempo que las FAL se sumían en una profunda crisis que acabaría poco después con su desmembramiento.

Quien sí logró una influencia significativa en la dirección del SITRAC fue el maoísta Vanguardia Comunista ${ }^{39}$. VC fue de los primeros en volcar sus fuerzas hacia el proceso de Fiat, trabando contactos con los nuevos dirigentes y volcando a muchos de sus principales militantes a colaborar con el nuevo SITRAC, entre ellos Roberto Cristina, Sergio Ortiz, Silvio Resnik "el Grandote”, Eduardo Garbino Guerra y Andrés Rivera $^{40}$. En el transcurso del año 1970, en su periódico "No Transar" aparecían permanentes notas acerca

\footnotetext{
37 Sobre las FAL, ver Gabriel Rot, "Notas para una historia de la lucha armada en la Argentina. Las Fuerzas Argentinas de Liberación”, Politicas de la Memoria, Anuario CEDINCI, No 4, 2003. Stella Grenat, Una espada sin cabeza. Las FAL y la construcción del partido revolucionario en los '70, Buenos Aires, Ediciones RyR, 2010. Ariel Hendler, La guerrilla invisible. Historia de las Fuerzas Argentinas de Liberación, Buenos Aires, Vergara, 2010. Por razones de clandestinidad y políticas, durante mucho tiempo Masera negó que hubiera tenido cualquier clase de vínculos con las FAL, presentándose como "independiente". Aun así, en la época muchos conocían o inferían la relación, como se ve en las muchas referencias al rol de las FAL en el SITRAC presentes en los materiales de otras fuerzas. La cuestión terminó de aclararse a partir de que varios ex militantes de las FAL de Córdoba mencionaron haber sumado a Masera. En Grenat, op. cit., pp. 204 y 375. Y él mismo lo ratifica en sus últimas entrevistas.

38 Un militante de las FAL de Córdoba comenta: "Éramos un grupo armado, a nosotros nunca nos llegó un material político. [...] Leíamos por nuestra parte, sobre la Revolución Rusa, Cubana, Vietnamita, la Revolución China”. En Grenat, op. cit., p. 203. 39 Sobre VC, ver Soto, op. cit. Sergio Ortiz et. al., Vidas y luchas de Vanguardia Comunista: la generación del 70, sus ideas, militancia, aciertos y errores, Buenos Aires, Nuevos Tiempos, 2010. Adrián Celentano, "Maoísmo y nueva izquierda. La formación de Vanguardia Comunista y el problema de la construcción del partido revolucionario entre 1965 y 1969", en María Cristina Tortti, La nueva izquierda argentina (1955-1976), Rosario, Prohistoria, 2014. Brenda Rupar, "El partido Vanguardia Comunista: elementos para avanzar en una caracterización del maoísmo argentino (1965-1971)”, Izquierdas, No 36, Santiago de Chile, 2017.

${ }^{40}$ En 1970 el Comité Central de VC directamente se trasladó a Córdoba.
} 
de los sindicatos y las luchas de Fiat, posicionándolos como la vanguardia y el ejemplo a seguir nacionalmente ${ }^{41}$.

El primer y más importante logro que obtuvieron fue la incorporación de José Páez a las filas partidarias ${ }^{42}$. El "petiso" Páez había estudiado y trabajado en la Fábrica Militar de Aviones, e ingresó a Concord en 1955, con 19 años de edad. Según su relato, sus primeras intervenciones en la fábrica fueron en las cooperativas formadas tras el golpe de 1955, cuando las organizaciones sindicales estaban proscriptas, y en ese tiempo acompañó a su tío, militante de la UOM, en algunas acciones de la resistencia peronista. A inicios de los '60 toma contacto con los militantes del PO (T) en la Fiat: "conozco dos trotskistas del posadismo, que eran delegados, dos tipos macanudos, y ahí me ligo políticamente, conozco el trotskismo y empiezo a conocer más la izquierda". La derrota de la lucha de 1965 lo deja por los siguientes años sin una expectativa de poder cambiar la situación, hasta que sobreviene el Cordobazo. Masera relata:

Como yo había tenido relación con alguna gente de la izquierda, conversando, no militando, tenía siempre esa duda de la política y se lo comenté. Entonces hablábamos. Un día él se fue a la biblioteca de Fiat y sacó un libro que narraba la vida del Che, y eso terminó por entusiasmarnos más. ${ }^{43}$

Páez empezó a destacarse inmediatamente después de la asamblea de marzo, actuando con gran resolución en la primera toma de Concord y quedando como vocal en la nueva CD. Su personalidad combativa y la formación política e ideológica que comenzó a obtener a partir del inmediato vínculo con los intelectuales de $\mathrm{VC}$, terminaron por proyectarlo como uno de los principales y más politizados dirigentes del SITRAC. No por casualidad se contó entre los siete despidos que motivaron la toma de enero de 1971, en donde también jugó un gran papel logrando con su intervención en una asamblea que la toma fuera mantenida hasta obtener el triunfo. Desde 1968, Vanguardia Comunista impulsaba la creación de "Comisiones Obreras" clandestinas en los lugares de trabajo, las cuales finalmente articuló en febrero de 1971 en la llamada Tendencia Obrera Revolucionaria y Clasista "29 de Mayo" ${ }^{44}$. En ese sentido, encabezada por Páez y conformada por unos 40 delegados y trabajadores de Concord, VC promovió la Agrupación "14 de enero", que se proclamaba como "una agrupación clasista" unida en torno a "un programa y una línea de conducta sindical revolucionaria, para encarar en mejores condiciones la lucha reivindicativa de los obreros" $" 45$.

Tanto PyP, como los propios escritos partidarios y los de otras fuerzas hacen referencia a la significativa influencia que tuvo VC en la línea del SITRAC, al menos durante el primer año de la experiencia. Esta influencia se evidencia no solo en la adopción por el SITRAC de consignas de factura partidaria como "Ni golpe ni elección, revolución" o los puntos de contacto del Programa de SITRACSITRAM con la estrategia partidaria, sino esencialmente en la política de la dirección de Fiat hacia el movimiento obrero de Córdoba. Sin duda, VC tuvo una gran cuota de responsabilidad en el fuerte enfrentamiento contra la CGT local, a la que calificaba como una "cueva de gángsters y traidores" y "un sello repudiado por los obreros" 46 . Fue la tendencia que más firmemente rechazó los acuerdos dentro de la central obrera, impulsando acciones paralelas e independientes de lo que se resolvía en el plenario

${ }^{41}$ Ver por ej. No Transar, Órgano del Comité Central de Vanguardia Comunista, № 93, 5-10-70; № 94, 3-11-1970; № Extra, 23-1170. Entrevista a Sergio Ortiz. Entrevistador: Diego Salerno. Buenos Aires, 1993.

42 Entrevista a José Páez. Entrevistador: Diego Salerno. Buenos Aires, 1993.

${ }^{43}$ Entrevista a Carlos Masera, op. cit.

44 No Transar..., No 98, 1-9-1968; "Declaración de principios de la Tendencia Obrera Revolucionaria y Clasista 29 de Mayo", Boletin $N^{0} 1$ de la Agrupación Sindical 29 de Mayo, 2-1971, Archivo SITRAC/Subarchivo 19/Ficha 36.

45 Boletín 14 de Enero, № 1, 20-1-1971, Archivo SITRAC/Subarchivo 19/Ficha 36. En el Archivo del SITRAC se conservan más de una decena de boletines y volantes de la "14 de enero" que abarcan todo el año 1971.

46 Boletin 14 de Enero, No 2, 2-1971, Archivo SITRAC/Subarchivo 19/Ficha 36. 
provincial de gremios ${ }^{47}$, y rechazando "terminantemente" sumarse a la Comisión de Lucha y luego a la nueva conducción encabezada por López y Tosco, a quienes identificaba como las expresiones sindicales de los agrupamientos políticos encaminados hacia la salida electoral, La Hora del Pueblo y el Encuentro Nacional de los Argentinos ${ }^{48}$.

A través de VC fue también que llegó Susana Fiorito al SITRAC. A fines de los '50 esta había sido parte del núcleo de intelectuales que, liderados por Ismael Viñas, apoyó a la UCRI de Arturo Frondizi. Más tarde, decepcionados, constituyeron el Movimiento de Liberación Nacional (MLN), más conocido como MALENA, una organización de izquierda, marxista, con un marcado eje programático en la liberación nacional, en donde Fiorito ofició como miembro de su dirección durante casi toda la década del ' $60^{49}$. Tras la disolución del MLN y ya sin militancia partidaria, Fiorito aceptó una nueva propuesta política:

Vine a Córdoba invitada por militantes de Vanguardia Comunista para colaborar con la Comisión Directiva de SiTraC en la edición de un periódico. [...] Fui presentada a la CD del SiTraC a fin de noviembre o principios de diciembre de 1970. Me reunía diariamente con miembros de la CD (más frecuentemente con el Secretario de Prensa, Rafael Clavero; el Secretario General Carlos Masera y el Adjunto, Domingo V. Bizzi)..$^{50}$

Como secretaria del SITRAC, Fiorito tomó a su cargo la redacción del periódico sindical, la elaboración y distribución de comunicados de prensa, y la recopilación de todos los materiales que llegaban al local del sindicato. Según el relato de Masera, Fiorito tenía una importante influencia política sobre el Secretario de Prensa, Clavero, y muchos de los documentos del SITRAC tienen su marca: "La Fiorito escribía, se discutía en el Cuerpo de Delegados y se le hacía cambiar términos o la totalidad, lo que sea, pero ella tenía habilidad para meter su línea de cualquier forma" 51 . En ese período, a su vez, Fiorito mantuvo una cercanía con uno los dos grupos que se habían conformado tras la disolución del MLN cordobés, El Obrero ${ }^{52}$, y trabó una relación política muy cercana con Pedro Milesi.

Milesi era un viejo y respetado militante obrero que había llegado a Córdoba a fines de los años ' 40 tras una extensa trayectoria sindical y política que incluía el paso por las filas del anarquismo, el socialismo, el comunismo y el trotskismo y la participación directa en múltiples organizaciones sindicales y en hitos como el Grito de Alcorta, la Semana Trágica y el 17 de Octubre de $1945^{53}$. En la década del

47 La decisión de SITRAC-SITRAM de convocar a un acto propio el 29 de enero de 1971 abrió una intensa polémica en la izquierda sobre la política hacia la CGT cordobesa, con varias fuerzas responsabilizando a VC y calificándola de "aislacionista" (ver por ej. Política Obrera No 83, 8-2-1971; Nueva Hora, Órgano del Partido Comunista Revolucionario de la Argentina, No 61, 2da quincena 2-1971; No Transar... No 98, 15-3-1971).

48 El Maoísta, Boletín de los militantes de Vanguardia Comunista de Fiat, No 2, 1-1972, pp. 8, 9 y 13, Archivo SITRAC/Subarchivo 19/Ficha 38.

49 Julieta Pacheco, Nacional y popular. El MALENA y la construcción del programa de liberación nacional (1955-1969), Buenos Aires, Ediciones RyR, 2012.

${ }^{50}$ Entrevista a Fiorito, en Schmucler et. at., 2014: 335-336. En ese momento Fiorito estaba en pareja con Andrés Rivera, por entonces un activo militante de VC.

${ }^{51}$ Entrevista a Carlos Masera, op. cit.

${ }^{5}$ Julieta Pacheco, "La regional cordobesa del Movimiento de Liberación Nacional (MLN): un caso de radicalización política como producto de la agudización de la represión dictatorial (1966-1969)", Historia, Voces y Memoria, No 6, Programa de Historia Oral, FyL-UBA, 2013. Federico Cormick, "La Organización Comunista Poder Obrero y su perspectiva en el movimiento obrero. Una apuesta al clasismo: Del Sitrac Sitram a Villa Constitución”, en VIII Jornadas de Sociología de la UNLP, Buenos Aires, 2014. Páez afirma que "la Susana Fiorito simpatizaba más con ese grupo, con El Obrero". Entrevista a José Páez, op. cit.

53 "Pedro Milesi, su vida, su obra", Fundación Pedro Milesi y Biblioteca Popular de Bella Vista, Córdoba, 1984. Mariana Mastrángelo, “'Pedro Milesi, memorias de un viejo compañero'. Memoria individual y memoria colectiva en la conformación de una tradición de los oprimidos", en Magdalena Cajías de la Vega y Pablo Pozzi (comp.), Cultura de irquierda, violencia y política en América Latina, 
'60, ya como marxista independiente, había trabado vínculos con distintos sectores del movimiento obrero y estudiantil cordobés, entre ellos una amistad personal con Agustín Tosco, participando en charlas, cursos de historia y asambleas. Recibió con gran entusiasmo el resurgimiento del sindicalismo clasista, por lo que pronto se vinculó con los nuevos dirigentes de SITRAC-SITRAM, que lo acogieron como una suerte de padre espiritual. Como señala Mariana Mastrángelo:

La nueva generación sesentista y el clasismo obrero de fines de la década de 1960, encontraron en él precisamente eso: un obrero que no estaba vinculado ni a la tradición comunista ni a la trotskista, que había participado de gran parte de la historia obrera argentina, y que había encarnado en numerosos escritos, un espíritu crítico. ${ }^{54}$

De este modo, la presencia de "el viejo Pedro" era frecuente en el local de los sindicatos de Fiat, y sería elegido como uno de los miembros de la mesa que presidió el primer Congreso clasista nacional convocado por SITRAC-SITRAM, al cual definió como "el Grito de Córdoba", y donde llamó a "retomar los principios y los métodos del sindicalismo clasista y la acción directa" 55 .

A pesar de que en la CD solo tenía el cargo de vocal, como Páez, Gregorio Flores pronto se destacó como otro de los principales dirigentes del SITRAC. El "Goyo" había entrado a Fiat en 1959. Sin militancia ni conocimientos de política o sindicalismo, había participado activamente en la huelga y los piquetes de fábrica en 1962. En 1965, con la conformación del SITRAC, fue electo delegado, pero la derrota de la huelga de ese año lo impactó fuertemente:

Empecé a tomar conciencia de que había otras cosas, me empecé a preocupar por leer y pensar mejor este asunto de la política en la fábrica. Porque era evidente que la política estaba en la fábrica y que si uno la ignoraba no entendía nada y lo engatusaban fácilmente. ${ }^{56}$

Así, decidió retirarse de la acción sindical y dedicarse hacer el bachillerato y estudiar por su propia cuenta, leyendo libros de historia y marxismo y participando en cursos y charlas de los grupos socialcristianos. Tras un período ligado a estos últimos, terminó por afirmarse en el "independentismo".

La asamblea de marzo de 1970 lo decidió a volver a involucrarse, pero ahora ya con una formación un poco más sólida. Probablemente por esta razón es que fue uno de los que más actuó como vocero del SITRAC en las asambleas populares, en las reuniones con las fuerzas políticas o en actos estudiantiles, como el mencionado en el que se definió por el socialismo. Flores se reunía con todas las fuerzas, pero su relación prioritaria fue con el PRT: "Cuando nosotros llegamos al sindicato, en el '70, me ligué en seguida con un ex militante del Partido Comunista que se había pasado al PRT" 57.

Flores fue también uno de los despedidos de enero 1971. El 3 de marzo, en un acto convocado por el movimiento obrero cordobés donde habló en nombre del SITRAC, hizo otra fuerte definición política, muy festejada en el periódico del PRT: "dirigentes de Fiat hablaron claramente de un gobierno obrero y popular que construya el socialismo como única alternativa de este régimen y señalaron la vía armada como la única para lograr dicho gobierno" 58 . Luego del "Viborazo", Flores fue detenido y

Buenos Aires, CLACSO, 2015. Horacio Tarcus (dir.), Diccionario biográfico de la izquierda argentina. De los anarquistas a la "nueva irquierda” (1870-1976), Buenos Aires, Emecé, 2007. Revista Posición, Suplemento del No 13, 4-1974.

54 Mastrángelo, op.cit., p. 75.

55 Revista Posición, op. cit.

56 Flores, 2006, op. cit., p. 27.

57 Ibid., p. 30. Flores se refiere a Carlos Germán (el "Negro Mauro"), quien había trabajado en Fiat hasta 1965, y en 1970 se desempeñaba como responsable del PRT cordobés y miembro de su Buró Político nacional.

58 El Combatiente..., N53, 3-1970, p. 4. Flores, 2004, op. cit., p. 176. 
trasladado a las cárceles del sur, en donde permanecería hasta agosto de 1972. Cómo él mismo señala, "mi gran escuela política va a ser la cárcel de Rawson": allí trabó relación directa con Mario R. Santucho y la plana mayor del PRT, a donde terminaría por incorporarse ${ }^{59}$. La libertad de Flores se transformó en una de las principales banderas de los sindicatos de Fiat durante los seis meses que siguieron hasta su disolución, y el "Goyo" se mantuvo en contacto permanente con sus compañeros a través de cartas y declaraciones.

El PRT-ERP ${ }^{60}$ ha sido señalado como el partido que logró mayor influencia sobre los trabajadores de Fiat, sobre todo a partir del "Viborazo" ${ }^{61}$. Esta apreciación merecería matizarse: es muy probable que haya sido la organización que logró incorporar más dirigentes y obreros de este proceso, pero no es tan claro que sus posiciones hayan sido hegemónicas en SITRAC-SITRAM. De hecho, las principales orientaciones que planteó el PRT en su periódico fueron críticas de las posturas adoptadas por los dirigentes de Fiat. A mediados de 1971, inmediatamente después de la publicación del "Programa de SITRACSITRAM", el PRT publicó una importante nota titulada "El papel de los sindicatos" ${ }^{2}$. Allí festejaba la aparición de las direcciones clasistas, pero alertaba contra el peligro de "confundir las tareas del Partido y el Sindicato". Según el PRT, el rol de los organismos sindicales consistía en defender los intereses económicos de los trabajadores y desarrollar su conciencia política, pero "pretender que el sindicato se convierta en dirección de la lucha política del proletariado por la toma del poder" llevaba necesariamente a "una política sectaria y a una táctica sindical ultraizquierdista". Junto con esto, el partido cuestionó en duros términos que los sindicatos de Fiat hubieran "buscando mantenerse totalmente al margen de toda alianza o lucha de carácter circunstancial del resto de las direcciones sindicales, en aras de no manchar su 'pureza revolucionaria"', en una clara referencia al agrupamiento sindical encabezado por Tosco ${ }^{63}$.

Cuando se inició el proceso de Fiat en 1970, el centro de las preocupaciones del PRT estaba ubicado en el lanzamiento de la lucha armada. Tras la conformación del ERP en su V Congreso, realizado en julio de ese año, Roberto Santucho ubicó su centro de operaciones en la radicalizada Córdoba. Los mencionados antecedentes de Carlos Germán en Fiat y su temprano vínculo con Flores abrieron el camino para la intervención del PRT en el proceso de Fiat y una importante incorporación de militantes y simpatizantes, entre ellos el Adjunto del SITRAC Bizzi, el delegado Julio Oropel, Guillermo Torrandel y Juan Eliseo Ledesma, a lo hay que sumar a Eduardo Castelo Soto y Raúl Suffi de la dirección del SITRAM, y la mencionada relación con Curutchet ${ }^{64}$. Tanto Bizzi como Oropel y Flores sostienen que lo que los atrajo al PRT-ERP fue principalmente sus acciones armadas. Desde octubre de 1970, el ERP realizó una gran cantidad de acciones en Córdoba, incluyendo incautaciones y repartos de mercancía en barrios humildes, desarme de policías y copamientos, logrando una gran difusión en los medios cordobeses, y su presencia con volantes, pintadas y banderas fue particularmente visible durante las jornadas del Viborazo ${ }^{65}$.

${ }^{59}$ Flores, 2006, op. cit., pp. 33-34.

${ }^{60}$ Sobre el PRT-ERP, ver, entre otros, María Seoane, Todo o nada. La bistoria secreta y la bistoria pública del jefe guerrillero Mario Roberto Santucho, Buenos Aires, Debolsillo, 2009. Daniel De Santis, A vencer o morir: historia del PRT-ERP. Documentos, Buenos Aires, Nuestra América, 2006. Pablo Pozzi, "Por las sendas argentinas...”. El PRT-ERP. La Guerrilla Marxista, Buenos Aires, Imago Mundi, 2004. Santiago Stavale y Daniel De Santis, Un partido de la clase obrera. La política del PRT-ERP en el movimiento obrero, Buenos Aires, A formar filas, 2016. Leandro Inchauspe, “'La guerra revolucionaria ha comenzado'. La aparición pública del PRT-ERP en el escenario cordobés post Cordobazo (1970-1971)", en I Jornadas de Historiografía Regional, UNNE, Chaco, Argentina, 2006.

${ }^{61}$ Brennan, op. cit., p. 246. Brennan y Gordillo, op. cit., p. 139.

62 El Combatiente..., No $56,31-5-1971$.

63 El Combatiente..., No 66, 30-1-1972, p. 10.

${ }^{64}$ Es difícil precisar cuál fue el momento exacto en que cada uno se ligó al PRT, pero no cabe duda que la relación se estableció durante el proceso de SITRAC-SITRAM, particularmente desde fines de 1970.

${ }^{65}$ Inchauspe, op. cit. El 21 de diciembre de 1970, por ejemplo, un comando del ERP copó la guardia interna de Materfer. Diario Córdoba, 26-12-1971. Sobre las acciones del ERP durante el Viborazo, ver El Combatiente..., N53, 3-1971. 
Bizzi venía de una familia cercana al radicalismo. Había estudiado y trabajado desde los 12 años en la Fábrica Militar de Aviones, donde vivió la gran huelga de 1960 y fue despedido por hacer una colecta para un delegado despedido. Entró a la Fiat en 1965, donde lo eligieron delegado de su sección y comenzó a vincularse con otros delegados opositores a Lozano, como el mencionado Taverna. La oposición de estos a la firma del convenio fue lo que llevó a que se convocara la asamblea del 23 de marzo, que terminó abriendo el proceso de recuperación sindical y proyectando a Bizzi como parte de la nueva CD del SITRAC. Según su relato, su incorporación al PRT se produjo a inicios de 1971, en una reunión con Germán y Santucho, y estuvo marcada por la convicción de que

si uno quiere cambiar el sistema, dignificar al ser humano, indudablemente requiere de actuar con el mismo método que ellos actúan para defenderse. Ellos tienen el ejército como guardia pretoriana del sistema. ${ }^{66}$

En el mismo sentido van los relatos de Oropel y de Flores:

El Combatiente es el que principalmente yo alcanzo a conocer cuando conocí a la gente del PRT... En realidad, no era tanto, era el ERP el que se conocía. Inclusive, hace algunas operaciones. Se conocía por las operaciones que se hacían de propaganda armada. [...] Y al PRT yo lo elijo porque al principio era el que más operaciones militantes hacía y fue con el que se llegó más rápidamente a nosotros. Y porque había también gente que conocí que eran del PRT. El Negro Mauro, por ejemplo, que había sido un obrero del PC, que era del PRT. ${ }^{67}$

Mi atracción por el PRT tenía que ver con las cosas que la gente apreciaba de la guerrilla. La guerrilla hacía acciones militares que despertaban en la gente una gran simpatía: 'iQué cojones que tienen los locos estos!'.68

El propio periódico del PRT recogía, y remarcaba, esta simpatía. Durante la toma de Concord en enero de 1971, publicó un reportaje a un dirigente del SITRAC, que, ante la pregunta acerca de su opinión sobre las organizaciones armadas, respondió: "La gente lo vive, lo ve muy bien. Cuando el Ejército Revolucionario del Pueblo tomó la guardia aquí, después todos los compañeros andaban pintando estrellas en los baños y paredes"69.

Otra de las fuerzas que jugaron un rol central en el proceso de Fiat fue el Peronismo de Base ${ }^{70}$. Esto, que, como vimos, había sido señalado por PyP, quedó oscurecido en la interpretación de Brennan y Gordillo, quienes afirmaron que "virtualmente no había participación de activistas peronistas intransigentes como dirigentes dentro de los sindicatos clasistas de Fiat" ${ }^{\text {" }}$. El PB había tenido su origen justamente en la provincia de Córdoba tras el Cordobazo, a partir de la articulación de grupos barriales, estudiantiles y obreros, entre estos últimos uno conocido como el "grupo de Fiat", encabezado por

${ }^{66}$ Entrevista a Domingo Bizzi, en Área de Historia Oral..., op. cit.

${ }^{67}$ Entrevista a Julio Oropel. Entrevistadora: Marcela Santucho. Córdoba, 2010.

${ }^{68}$ Flores, 2006, op. cit., p. 34.

${ }^{69}$ El Combatiente..., N $\mathrm{N}^{\mathrm{O}}$ 51, 1-1971, p. 19.

${ }^{70}$ Sobre el PB y las Fuerzas Armadas Peronistas (FAP), ver Cecilia Luvecce, La Fuerzas Armadas Peronistas y el Peronismo de Base, Buenos Aires, CEAL, 1993. Eduardo L. Duhalde y Eduardo Pérez, De Taco Ralo a la alternativa independiente. Historia documental de las Fuerzas Armadas Peronistas y del Peronismo de Base, Buenos Aires, De la Campana, 2002. Marcelo Raimundo, "Izquierda peronista, clase obrera y violencia armada: Una experiencia alternativa”, Sociohistórica, No 15-16, 2004.

${ }^{71}$ Brennan, op. cit., p. 232. Brennan y Gordillo, op. cit., p. 127. 
Florencio Díaz de Materfer ${ }^{72}$. Reivindicaba el peronismo y la figura de Perón, pero se proponía desarrollar una organización independiente con "una estrategia alternativa y revolucionaria para el peronismo a partir del trabajo antiburocrático en las bases", integrando categorías del marxismo como la lucha de clases a sus interpretaciones acerca de la sociedad y del propio movimiento peronista, y postulando como objetivo la liberación nacional y el socialismo, lo que sostenía "solamente podrá ser alcanzado por la guerra popular revolucionaria a través de su máxima expresión que es la lucha armada". Esto a su vez lo llevaba a priorizar las alianzas con las organizaciones armadas, tanto peronistas como no peronistas, y con la izquierda revolucionaria en general ${ }^{73}$. En un congreso realizado en julio de 1971, el PB se transformó en una organización nacional, constituyendo las Agrupaciones "26 se Julio".

Hacia mediados de 1970, el PB cordobés estableció una estrecha relación con las Fuerzas Armadas Peronistas, y muchos de sus miembros actuaban simultáneamente en esta organización armada ${ }^{74}$. La principal acción de las FAP relacionada con SITRAC-SITRAM fue la llamada "Batalla de Fiat", tras la disolución represiva de los sindicatos. El 3 de noviembre de 1971, en un operativo conjunto con FAR y Montoneros, se intentó el secuestro de un ejecutivo de Fiat. Descubiertos por la policía provincial, se desencadenó un tiroteo que culminó con la muerte de cuatro de los miembros de las organizaciones armadas, entre ellos el dirigente de las FAR Carlos Olmedo ${ }^{75}$.

El PB remarcaba la importancia del trabajo político en los sindicatos, pero señalaba constantemente que "el régimen ha ido creando un enjambre de anticuerpos que 'limitan su accionar a la mera acción reivindicativa', desligándola de toda política y estrategia de poder" ${ }^{\prime 76}$. De este modo, su estrategia se orientaba fundamentalmente hacia el trabajo entre las bases y la construcción de agrupaciones peronistas de base, lo que conllevaba un importante "desprecio" "por los ámbitos considerados 'superestructurales"'77. Es probablemente por este motivo que muchas veces la presencia del PB en SITRAC-SITRAM quedó invisibilizada. Como ya mencionamos, el propio Secretario General del SITRAM, Florencio Díaz, pertenecía al PB. Pero también en el SITRAC, si bien no ubicó miembros en la CD, esta fuerza tuvo un peso más que relevante: según Masera, era claramente la primera minoría en el Cuerpo de Delegados de Concord, y era por esa razón que el segundo abogado, Federico, era un hombre del peronismo revolucionario ${ }^{78}$. La siguiente cita del periódico Evita, realizada el marco de la discusión por el convenio en Fiat, ilustra la reivindicación del clasismo y las orientaciones de este grupo: el PB llamaba a los obreros a seguir luchando por las reivindicaciones,

pero siempre teniendo en cuenta que la verdadera solución de nuestros problemas se va a dar cuando derribemos al sistema de explotación vigente, y por ello es necesario mantener la dirección clasista y revolucionaria de nuestro gremio. ${ }^{79}$

Antonio Palada fue uno de los principales referentes del PB de Concord. Su madre, viuda, había sido una activa militante del peronismo, referenciada en particular con Eva Perón, y él había trabajado

\footnotetext{
72 Duhalde y Pérez, op. cit., p. 63-65. Entrevista del autor a Juan "El Topo” Agüero, Córdoba, 17-11-18. Agüero fue miembro del equipo de prensa del Peronismo de Base cordobés, delegado del gremio bancario e integrante de las FAP.

${ }^{73}$ Cristianismo y Revolución, No 29, 6-1971, pp. 11-13; No 30, 9-1971, pp. 9-12.

${ }^{74}$ Raimundo, op. cit., p. 119. Entrevista del autor a Juan "El Topo" Agüero, op. cit.

75 Duhalde y Pérez, op. cit., pp. 215-216. Diario Los Principios, Córdoba, 4-11-1971.

${ }^{76}$ Boletin Evita, Órgano de difusión del Peronismo de Base Regional Córdoba, No 9, 10-1971, p. 6.

77 Raimundo, op. cit., p. 121.

${ }^{78}$ Entrevista a Carlos Masera, op. cit. En el mismo sentido, en una reseña del Congreso convocado por SITRAC-SITRAM, la Revista Nuevo Hombre señalaba acerca del PB: "Su fuerza es hegemónica en las bases de SITRAC-SITRAM". Nuevo Hombre, No 10, 22-9-1971, p. 11.

${ }^{79}$ Boletin Evita..., No 8, 7-1971, p. 4.
} 
desde chico en una fábrica del plástico ${ }^{80}$. Su entrada a la Fiat se produjo en 1963, donde participó de la derrotada lucha de 1965, y en 1969 fue herido durante los enfrentamientos del Cordobazo. A esa altura ya tenía vínculos con los núcleos originarios del Peronismo de Base cordobés, y poco después se incorporó también a un comando de las FAP. Según su relato, fue una decisión deliberada del PB no incorporarse a la CD del nuevo SITRAC: "¿Cuál fue la estrategia nuestra? Manejar el Cuerpo de Delegados. Ahí nosotros votábamos, íbamos a la asamblea y si era necesario dábamos vuelta las asambleas cuando las cosas no iban bien". Palada fue uno de los primeros despedidos producto de la ofensiva de la Fiat contra el nuevo SITRAC, en diciembre de 1970, lo que motivó varias medidas de lucha y una huelga de hambre en la parroquia de Ferreira en la navidad de ese año.

Por último, debemos referirnos al rol del Partido Comunista Revolucionario ${ }^{81}$, cuya influencia en el proceso de SITRAC-SITRAM ha sido muchas veces sobreestimada, como se ve incluso en la cita de Pasado y Presente. Al momento del inicio de la experiencia de Fiat, el PCR tenía ya una significativa fuerza en la provincia de Córdoba, con militantes en el movimiento estudiantil, intelectuales y profesionales, y, más importante aún, una influencia importante entre los trabajadores del SMATA cordobés, sobre todo en la matricería Perdriel ${ }^{82}$. En el plano sindical, el partido impulsaba las Agrupaciones Clasistas Primero de Mayo, que en diciembre de 1970 llevaron a cabo su primer Plenario Nacional en la propia ciudad de Córdoba ${ }^{83}$.

El PCR no logró obtener fuerza propia en la Comisión Directiva del SITRAC. Si bien estableció contactos con varios de los principales referentes, su principal incorporación fue un delegado, Raúl "el Ratón” Seré, quien junto con algunos otros trabajadores conformó la agrupación Primero de Mayo de Concord ${ }^{84}$. Un balance interno de la Regional Córdoba del PCR ${ }^{85}$ describe claramente la cuestión: señala que, al principio, concentrados en el proceso del SMATA, solo "se siguió a Fiat como algo ajeno" "86. Hacia fines de 1970, cuando SITRAC-SITRAM comenzó a destacarse, se caracterizaba que "las fuerzas del Partido en Fiat eran muy pequeñas" y "no teníamos línea para abordarlo". Cuando se produjo la definición clasista de los sindicatos a inicios de 1971, "fue recién aquí que el Partido nacionalmente cobra conciencia de Fiat".

El principal elemento que llevó a que la influencia partidaria pareciera mayor de lo que era fueron las similitudes que tuvo el Programa de SITRAC-SITRAM con las definiciones programáticas que por entonces defendía el PCR. Este fue quien más reivindicó y difundió el Programa de Fiat, señalando que "constituye toda una política proletaria para una revolución social y nacional camino del socialismo" $87, \mathrm{y}$

${ }^{80}$ Entrevista del autor a Antonio Palada, Córdoba, 17-11-2018.

81 Sobre el PCR, se pueden ver Pilar Sánchez, El gordo Antonio. Vida, pasión y asesinato del dirigente comunista revolucionario César Gody Álvarez, Buenos Aires, Ágora, 2008. Brenda Rupar, "El Partido Comunista Revolucionario: de su ruptura con el Partido Comunista Argentino a su adopción del maoísmo (1967-1974)", en Brice Calsapeu Losfeld y Miguel Ángel Urrego Ardilla (Coord.), La década roja (1966-1976), Morelia-México, IIH/UMSNH, 2018. Matías Rubio, "El Partido Comunista Revolucionario y su ingreso a la producción historiográfica; una interpretación histórica a su período formativo", Izquierdas, № 46, Santiago de Chile, 2019. Santiago Siskindovich, "El Partido Comunista Revolucionario y la construcción de la delimitación con el Partido Comunista Argentino (1968-1969)”, Izquierdas, No 49, Santiago de Chile, 2019.

82 Rodolfo Laufer, "El clasismo en el SMATA Córdoba. Ocupaciones fabriles, democracia sindical e izquierda clasista: la toma de la matricería Perdriel, mayo de 1970”, Estudios del Trabajo, No 49, ASET, Buenos Aires, 2016.

83 Nueva Hora..., No 57, 2 da quincena 12-1970, pp. 4-5.

${ }^{84}$ Entrevista del autor a Agustín Funes, Córdoba, 28-4-2014.

85 "Balance de la Zona Córdoba", Partido Comunista Revolucionario de Córdoba, fines 1971, pp. 12-14.

${ }^{86}$ Efectivamente, en el Boletín "El Compañero" de las Agrupaciones Primero de Mayo de Córdoba, publicado tras la toma de Concord de mayo de 1970, se criticaba a la Comisión Provisoria por sus "vacilaciones" y por intentar cumplir los pasos legales para la destitución de Lozano, y se desconfiaba de la posibilidad de lograr la realización de elecciones que consagren una dirección representativa de las bases: "Una dirección clasista no se obtiene pactando elecciones en el marco de lo que es hoy legalidad sindical". El Compañero, Órgano de las Agrupaciones "Primero de Mayo", 5-1970. Archivo de SITRAC/Subarchivo 20/Ficha 17.

87 Nueva Hora..., N 69, 1 era quincena 6-1971, p. 4. 
en el mencionado balance interno se lo definió directamente como "un abierto triunfo de nuestra línea" 88 . Cómo fue que esto llegó a ser así merece un análisis más profundo, pero, tal como lo señaló PyP en su momento, y lo corroboran nuestras indagaciones, más que haber sido una expresión de un rol dirigente del PCR en el proceso de Fiat, "los hechos muestran, sin embargo, que no fue más que el producto circunstancial de la influencia de una organización, el PCR, sobre las direcciones sindicales" 89 , y en particular sobre Curutchet, que fue quien redactó el texto.

Finalmente, el balance general de la experiencia realizado por el Comité Central del PCR fue de los más críticos de los elaborados por los grupos de la izquierda que reivindicaban el clasismo ${ }^{90}$. Según este, en SITRAC-SITRAM había terminado por predominar la "concepción comandista del militarismo pequeño burgués", lo que conllevaba una política de división de esferas: "el proletariado queda restringido a la lucha reivindicativa, mientras los grupos asumen la lucha estratégica por el poder", lo que fue la causa que llevó finalmente al aislamiento y la derrota de la experiencia.

\section{Palabras finales}

En este artículo ofrecemos un panorama general acerca de la intervención de las izquierdas en el proceso de SITRAC-SITRAM. Señalamos cuáles fueron en concreto las organizaciones que participaron de la experiencia logrando una fuerza propia al nivel de las direcciones de Fiat y algunas de sus orientaciones para la acción política y sindical. Si bien el proceso de los trabajadores de Fiat está lejos de reducirse al papel de las izquierdas, consideramos que este tampoco puede comprenderse integralmente prescindiendo de un análisis pormenorizado de este factor.

Los trabajadores de Fiat, y en particular su nuevo núcleo dirigente, realizaron un acelerado proceso de politización, que se asentó fundamentalmente en la situación de radicalización general que se vivía en la Argentina y en la provincia en el escenario post-Cordobazo, y en la propia dinámica de confrontaciones en que se encontraron embarcados a partir del intento de establecer una dirección sindical representativa de las bases. Sobre este terreno, fue la intervención de las izquierdas lo que terminó de aportarle una dirección específica a esta politización creciente. Como señalan los testimonios, el propio concepto de clasismo fue tomado del acervo de la izquierda porque consideraban que se ajustaba a lo que estaban viviendo, y fue al calor del contacto con los militantes de la nueva izquierda que los nuevos dirigentes fueron renovando sus concepciones ideológicas, políticas y gremiales. De este modo, en nuestra perspectiva una comprensión integral del sindicalismo clasista de los '70 exige necesariamente abordar la interrelación dialéctica entre sus prácticas distintivas y sus fundamentaciones, así como entre la experiencia obrera en dicha coyuntura histórica y sus vínculos con la nueva izquierda revolucionaria.

Durante su transcurso, el proceso de SITRAC-SITRAM estuvo sujeto la influencia de múltiples organizaciones, que coexistieron y mantuvieron una permanente disputa, realizando aportes parciales y cambiantes. Desde nuestro punto de vista, no se puede hablar de una fuerza que haya sido hegemónica, más allá de señalar que en una primera etapa Vanguardia Comunista parece haber sido la que marcó lo principal de las orientaciones hacia la CGT y el movimiento obrero local, y que en un segundo momento el PRT-ERP logró ganar a una sorprendente cantidad de dirigentes y activistas. Es de destacar también el peso y la atracción que lograron las organizaciones armadas entre los dirigentes de Fiat, tanto las de cuño marxista (ERP y FAL), como las del peronismo (FAP), todas las cuales se encontraban en los momentos iniciales de su apuesta por la acción político-militar y de la configuración de sus estrategias sindicales. El rol del Peronismo de Base, una de las fuerzas de la izquierda peronista que se identificó

\footnotetext{
88 "Balance de la Zona Córdoba", op. cit., p. 14.

${ }^{89}$ Pasado y Presente, en Schmucler et. at., op. cit., p. 181.

90 "Comandismo: una línea de derrota", Comité Central del Partido Comunista Revolucionario, 30-11-1971.
} 
plenamente con el sindicalismo clasista, aparece como un punto fundamental que exige un estudio más profundo, el cual aportaría para comprender mejor el nivel de radicalización política de un sector de las bases obreras, aún dentro de su identidad peronista.

A pesar de la heterogeneidad de fuerzas, lo que en general parece haber predominado en las direcciones de Fiat fue el intento de poner por delante los puntos generales de acuerdo, priorizando la identidad y los intereses de clase por encima de las distintas ubicaciones políticas. Un delegado del SITRAC señalaba en su momento: "No hay la rivalidad demostrada dentro del estudiantado por tendencias. En los estudiantes, habla una tendencia y chicanea a la otra, en los obreros no. Inclusive se coincide en muchos puntos, vamos, como yo diría, todos para el mismo lado. Se trabaja todos mucho más juntos" ${ }^{\prime}$. Y en el mismo sentido se expresaba Curutchet. hablando del propósito que los había animado con la formulación del "Programa de SITRAC-SITRAM":

Desde hace largo tiempo SiTraC y SiTraM tenían planteado enunciar un programa que permitiera detectar aquello que nos unía detrás de nuestra línea clasista. Que nos permitía, por encima del alineamiento que se estaba dando por parte de los principales activistas detrás de tendencias que, en cierto modo, están ligadas a partidos políticos revolucionarios existentes, que nos permitiera más allá de diferencias ideológicas, encontrar pautas comunes que nos unieran en la lucha, ya que todos estamos genéricamente ligados por el común propósito de construir el socialismo. ${ }^{92}$

La ubicación de las distintas fuerzas políticas que actuaron en SITRAC-SITRAM bajo el común paraguas que ofrecía el concepto de clasismo contribuyó a este propósito, aunque en ocasiones llevó a practicar posiciones cambiantes o contradictorias, y a intentar "promediar" las distintas estrategias y orientaciones sin terminar de conformar a ninguno. En este sentido, cabe destacar que las izquierdas influyeron en el proceso de Fiat tanto como este influyó en las izquierdas. Muchas de las fuerzas de la nueva izquierda estaban dando los primeros pasos en la sistematización de sus estrategias sindicales, por lo que la experiencia de SITRAC-SITRAM ofició como una suerte de laboratorio de la que cada una intentó extraer enseñanzas al tiempo que se esforzaba por ofrecer alguna clase de orientación.

Cada una de las definiciones importantes de los nuevos sindicatos fueron motivo de debates entre las distintas fuerzas y sus militantes en Fiat, cuya reconstrucción entendemos contribuiría a ver la experiencia con una mayor complejidad. Entre estos, tuvieron especial relevancia las polémicas acerca de la política a darse hacia la CGT y el movimiento obrero cordobés, la relación entre sindicalismo y política revolucionaria, el Programa de SITRAC-SITRAM, el Congreso nacional clasista de agosto de 1971 y sobre la represión y disolución de los sindicatos. Del mismo modo, los balances generales que cada organización -y aquí incluimos también a las que no tuvieron fuerza propia en Fiat- elaboró sobre el proceso tras la disolución de los sindicatos fueron sumamente contradictorios, lo que es central para comprender cómo orientaron sus intervenciones en sus posteriores intervenciones sindicales.

Finalmente, un análisis integral de la experiencia de los trabajadores de Fiat requiere saldar la cuenta pendiente que deja el desbalance entre lo que conocemos sobre el proceso del SITRAC y sobre la otra mitad del binomio: el SITRAM. La menor accesibilidad en cuanto a fuentes documentales no debería ser un obstáculo para dicha tarea.

Como señalamos al inicio, entendemos este artículo como un puntapié inicial que permita avanzar en futuras indagaciones que ahonden sobre las respectivas intervenciones de cada fuerza en la experiencia de SITRAC-SITRAM, y en general en el movimiento obrero del período. Dicho estudio aportaría a

\footnotetext{
${ }^{91}$ En Schumcler et. al, op. cit., p. 266. Si esto fue así entre los propios trabajadores, muchos testimonios señalan, por el contrario, la virulencia de los debates en los que intervenían los referentes o dirigentes de las organizaciones políticas de las izquierdas.

92 En Schumcler et. al, op. cit., p. 316.
} 
enriquecer el estudio acerca de las distintas estrategias y las corrientes sindicales en pugna en los años '70, una de las expresiones de las fuerzas sociales que estaban confrontando en el conjunto de la sociedad argentina.

\section{Bibliografía citada}

- Fernando Aizicson, Cultura política, militantes y movilización: Neuquén durante los años '90, Buenos Aires, Prometeo, 2017.

- Guillermo Almeyra, Militante crítico: una vida de lucha sin concesiones, Buenos Aires, Continente, 2013.

- José Aricó, La cola del diablo. Itinerario de Gramsci en América Latina, Buenos Aires, Puntosur, 1988.

- Beba Balvé, Miguel Murmis, Juan C. Marín, Lidia Aufgang, Tomás J. Bar, Beatriz Balvé y Roberto Jacoby, Lucha de calles, lucha de clases, Buenos Aires, Ediciones RyR, 2006.

- Roberto Baschetti, Militantes del peronismo revolucionario uno $x$ uno, http://www.robertobaschetti.com/uno $\% 20 \mathrm{x} \% 20$ uno.htm.

- Jorge Bergstein, El "Cordobazo". Memorias, testimonios, reflexiones, Buenos Aires, Cartago, 1987.

- Abel Bohoslavsky, "Biografías y relatos insurgentes. La historia del PRT en la memoria de Abel Bohoslavsky”, Sísifo, Año I, No 1, SITOSPLAD, Buenos Aires, 2011

- James P. Brennan, El Cordobazo. Las guerras obreras en Córdoba 1955-1976, Buenos Aires, Sudamericana, 1996.

- James P. Brennan y Mónica Gordillo, Córdoba rebelde. El Cordobazo, el clasismo y la movilización social, La Plata, De la Campana, 2008.

- Raúl Burgos, Los gramscianos argentinos. Cultura y politica en la experiencia de Pasado y Presente, Buenos Aires, Siglo XXI, 2004.

- Adrián Celentano, "Maoísmo y nueva izquierda. La formación de Vanguardia Comunista y el problema de la construcción del partido revolucionario entre 1965 y 1969", en María Cristina Tortti, La nueva izquierda argentina (1955-1976), Rosario, Prohistoria, 2014.

- Osvaldo Coggiola, Historia del trotskismo en Argentina y América Latina, Buenos Aires, Ediciones RyR, 2006.

- Aníbal Córdoba, El "Cordobazo”. Apuntes de un combatiente, Buenos Aires, Anteo, 1971.

- Federico Cormick, "La Organización Comunista Poder Obrero y su perspectiva en el movimiento obrero. Una apuesta al clasismo: Del Sitrac Sitram a Villa Constitución”, en VIII Jornadas de Sociología de la UNLP, Buenos Aires, 2014.

- Rubén Correa y Carlos Holmquist, "Estudios sobre el peronismo revolucionario: el FRP en Salta, 19721975", en X Jornadas Interescuelas de Historia, Catamarca, UNCA, 2011.

- Horacio Crespo, “En torno a Cuadernos de Pasado y Presente, 1968-1983”, en Claudia Hilb (comp.), El político y el cientifico. En sayos en homenaje a Juan Carlos Portantiero, Buenos Aires, Siglo XXI, 2009.

- Francisco Delich, Crisis y protesta social. Córdoba 1969-1973, Buenos Aires, Siglo XXI, 1974.

- Daniel De Santis, A vencer o morir: historia del PRT-ERP. Documentos, Buenos Aires, Nuestra América, 2006.

- Eduardo L. Duhalde y Eduardo Pérez, De Taco Ralo a la alternativa independiente. Historia documental de las Fuerzas Armadas Peronistas y del Peronismo de Base, Buenos Aires, De la Campana, 2002.

- Natalia Duval [Susana Fiorito], Los sindicatos clasistas: SiTraC (1970-1971), Buenos Aires, CEAL, 1988.

- Roberto Ferrero, "La implantación del trotskismo en Córdoba", en En la huella de Abelardo. Ensayos de izquierda nacional, Córdoba, Ediciones del CEPEN, 2013.

- Roberto Ferrero, "El Cuqui Curutchet que conocî", inédito, 2018.

- Gregorio Flores, SITRAC-SITRAM. La lucha del Clasismo contra la Burocracia Sindical, Córdoba, Espartaco, 2004. 
- Gregorio Flores, Lecciones de batalla. Una bistoria personal de los '70, Buenos Aires, Ediciones RyR, 2006

- Manuel Gaggero, "Morir en Buenos Aires”, en Página 12, 10-1-2006.

- Mónica Gordillo, Córdoba en los '60. La experiencia del sindicalismo combativo, Córdoba, REUN, 1996.

- Stella Grenat, Una espada sin cabeza. Las FAL y la construcción del partido revolucionario en los '70, Buenos Aires, Ediciones RyR, 2010.

- Leandro Inchauspe, “'La guerra revolucionaria ha comenzado'. La aparición pública del PRT-ERP en el escenario cordobés post Cordobazo (1970-1971)", en I Jornadas de Historiografía Regional, UNNE, Chaco, Argentina, 2006.

- Rodolfo Laufer, "El clasismo en el SMATA Córdoba. Ocupaciones fabriles, democracia sindical e izquierda clasista: la toma de la matricería Perdriel, mayo de 1970", Estudios del Trabajo, No 49, ASET, Buenos Aires, 2016.

- Rodolfo Laufer, "La CGT clasista de Salta, 1973", Documentos y Comunicaciones 2017, PIMSA, Buenos Aires, pre-edición digital. http://www.pimsa.secyt.gov.ar/novedades/La CGT clasista de Salta 1973.pdf.

- Cecilia Luvecce, La Fuerzas Armadas Peronistas y el Peronismo de Base, Buenos Aires, CEAL, 1993.

- Mariana Mastrángelo, “'Pedro Milesi, memorias de un viejo compañero'. Memoria individual y memoria colectiva en la conformación de una tradición de los oprimidos”, en Magdalena Cajías de la Vega y Pablo Pozzi (comp.), Cultura de izquierda, violencia y política en América Latina, Buenos Aires, CLACSO, 2015.

- Héctor Menéndez, "El fracaso de la dirección obrera y las causas de la derrota después del Cordobazo", Ponencia en Jornadas "A 40 años del Cordobazo", Córdoba, mayo 2009.

- Carlos Mignon, Córdoba obrera. El sindicato en la fábrica 1968-1973, Buenos Aires, Imago Mundi, 2014.

- Massimo Modonessi, El principio antagonista. Marxismo y acción política, México, Ítaca, 2016.

- María Laura Ortiz, Violencia y represión. Los trabajadores clasistas en Córdoba, 1969-1976, Buenos Aires, Tesis de Doctorado inédita, FFyL-UBA, 2015.

- Esteban Rafael Ortiz, Los abogados delpueblo. El derecho contra elpoder. El caso del Dr. Alfredo "Cuqui" Curutchet (1969-1974), Narvaja, 2007.

- Sergio Ortiz et. al., Vidas y luchas de Vanguardia Comunista: la generación del 70, sus ideas, militancia, aciertos y errores, Buenos Aires, Nuevos Tiempos, 2010.

- Julieta Pacheco, Nacional y popular. El MALENA y la construcción del programa de liberación nacional (19551969), Buenos Aires, Ediciones RyR, 2012.

- Julieta Pacheco, "La regional cordobesa del Movimiento de Liberación Nacional (MLN): un caso de radicalización política como producto de la agudización de la represión dictatorial (1966-1969)", Historia, Voces y Memoria, No 6, Programa de Historia Oral, FyL-UBA, 2013.

- Pablo Pozzi, "Por las sendas argentinas...”. El PRT-ERP. La Guerrilla Marxista, Buenos Aires, Imago Mundi, 2004.

- Marcelo Raimundo, "Izquierda peronista, clase obrera y violencia armada: Una experiencia alternativa", Sociohistórica, No 15-16, 2004.

- Susana Roitman, Hernán Tejerina, Ximena Cabral y Emilia Olivera, El torno y la molotov. Relatos e imágenes de la Córdoba obrera 60-70, Córdoba, Universitas, 2010

- Gabriel Rot, "Notas para una historia de la lucha armada en la Argentina. Las Fuerzas Argentinas de Liberación", Políticas de la Memoria, Anuario CEDINCI, N 4, 2003.

- Matías Rubio, "El Partido Comunista Revolucionario y su ingreso a la producción historiográfica; una interpretación histórica a su período formativo", Izquierdas, No 46, Santiago de Chile, 2019.

- Brenda Rupar, "El partido V anguardia Comunista: elementos para avanzar en una caracterización del maoísmo argentino (1965-1971)", Izquierdas, No 36, Santiago de Chile, 2017. 
- Brenda Rupar, "El Partido Comunista Revolucionario: de su ruptura con el Partido Comunista Argentino a su adopción del maoísmo (1967-1974)", en Brice Calsapeu Losfeld y Miguel Ángel Urrego Ardilla (Coord.), La década roja (1966-1976), Morelia-México, IIH/UMSNH, 2018.

- Pilar Sánchez, El gordo Antonio. Vida, pasión y asesinato del dirigente comunista revolucionario César Gody Álvarez, Buenos Aires, Ágora, 2008.

- Héctor Schmucler, J. Sebastián Malecki y Mónica B. Gordillo, El obrerismo de pasado y presente: Documento para un dossier no publicado sobre SiTraC-SiTraM, Córdoba, Eduvim, 2014.

- María Seoane, Todo o nada. La bistoria secreta y la bistoria pública del jefe guerrillero Mario Roberto Santucho, Buenos Aires, Debolsillo, 2009.

- Santiago Siskindovich, "El Partido Comunista Revolucionario y la construcción de la delimitación con el Partido Comunista Argentino (1968-1969)", Irquierdas, No 49, Santiago de Chile, 2019.

- Américo Soto, Vidasy Luchas de Vanguardia Comunista, Buenos Aires, Nuevos Tiempos, 2010.

- Santiago Stavale y Daniel De Santis, Un partido de la clase obrera. La política del PRT-ERP en el movimiento obrero, Buenos Aires, A formar filas, 2016.

- Horacio Tarcus (dir.), Diccionario biográfico de la izquierda argentina. De los anarquistas a la "nueva izquierda" (1870-1976), Buenos Aires, Emecé, 2007.

- Rubén Vianoli [Jorge Canelles], ¿Clasismo o aventurerismo? SITRAC-SITRAM. Experiencias y enseñanzas, Buenos Aires, Anteo, 1972.

\section{Fuentes documentales citadas}

- SITRAC, Boletin del Sindicato Trabajadores Concord, No 1, 13-1-71, Archivo de SITRAC/Subarchivo 1/Ficha 1.

- "SITRAC y SITRAM. Al pueblo de Córdoba", Comunicado de SITRAC-SITRAM, 8-2-1971, Archivo de SITRAC/Subarchivo 13/Ficha 9.

- "Programa de SITRAC-SITRAM", Ponencia de SiTraC-SiTraM al Plenario de Gremios Combativos, Archivo de SITRAC/Subarchivo 7/Ficha 1.

- "Plan de Lucha aprobado en el Plenario convocado por SITRAC-SITRAM el día 28 de agosto de 1971". Archivo de SITRAC/Subarchivo 7/Ficha 6b.

- Diario Los Principios, Córdoba, 4-11-1971.

- Diario Córdoba, Córdoba, 5-5-1970, 26-12-1971.

- Revista Panorama, No 202, 9 al 15-3-1971.

- La Mulita, Periódico de los trabajadores comunistas de Fiat, No 9, 9-1971, Archivo de SITRAC/Subarchivo 18/Ficha 9.

- Voz Proletaria. Órgano del Partido Obrero (Trotskista), No 663, 13-9-1970; № 671, 5-6-1971; № 677, 17-71971; No 693, 6-11-1971.

- El Combatiente, Órgano del Partido Revolucionario de los Trabajadores, No 51, 1-1971; N53, 3-1970; Nº 56, 31 5-1971; No 66, 30-1-1972; No 182, 10-9-1975.

- No Transar, Órgano del Comité Central de Vanguardia Comunista, No 93, 5-10-70; No 94, 3-11-1970; No Extra, 23-11-70; No 98, 1-9-1968.

- "Declaración de principios de la Tendencia Obrera Revolucionaria y Clasista 29 de Mayo", Boletín No 1 de la Agrupación Sindical 29 de Mayo, 2-1971, Archivo SITRAC/Subarchivo 19/Ficha 36.

- Boletín 14 de Enero, No 1, 20-1-1971; No 2, 2-1971. Archivo SITRAC/Subarchivo 19/Ficha 36.

- El Maoista, Boletín de los militantes de Vanguardia Comunista de Fiat, No 2, 1-1972, Archivo SITRAC/Subarchivo 19/Ficha 38.

- Boletín Evita, Órgano de difusión del Peronismo de Base Regional Córdoba, No 8, 7-1971; No 9, 10-1971. 
- Nueva Hora, Órgano del Partico Comunista Revolucionario de la Argentina, No 57, 2da quincena 12-1970; No 61, 2da quincena 2-1971; No 69, 1era quincena 6-1971.

- El Compañero, Órgano de las Agrupaciones "Primero de Mayo", 5-1970. Archivo de SITRAC/Subarchivo 20/Ficha 17.

- "Balance de la Zona Córdoba", Partido Comunista Revolucionario de Córdoba, fines 1971.

- "Comandismo: una línea de derrota", Comité Central del Partido Comunista Revolucionario, 30-11-1971.

- Política Obrera No 83, 8-2-1971.

- Cristianismo y Revolución, No 29, 6-1971; No 30, 9-1971.

- Nuevo Hombre, No 10, 22-9-1971.

- Revista Posición, Suplemento del No 13, 4-1974.

- "Pedro Milesi, su vida, su obra", Fundación Pedro Milesi y Biblioteca Popular de Bella Vista, Córdoba, 1984.

- "Informe preliminar sobre el conflicto de Fiat", Pasado y Presente, No 9, abril-septiembre 1965.

\section{Fuentes testimoniales citadas}

- Entrevista del autor a Carlos Masera, Córdoba, 20-11-18.

- Entrevista del autor a María del Carmen Curutchet, Córdoba, 24-11-18.

- Entrevista del autor a Alfio Taverna, Vía telefónica: Buenos Aires-Santiago del Estero, 17-1-2019.

- Entrevista del autor a Antonio Palada, Córdoba, 17-11-2018.

- Entrevista del autor a Juan "El Topo" Agüero, Córdoba, 17-11-18.

- Entrevista del autor a Agustín Funes, Córdoba, 28-4-2014.

- Entrevista del autor a Manuel Justo Gaggero, Buenos Aires, 1-2-2019.

- Entrevista del autor a Armando Jaime, Salta, 3-10-2016.

- Entrevista a Carlos Masera, Revista Los '70, o 8, Buenos Aires, 1997.

- Entrevista a Domingo Bizzi. Entrevistadora: Damiana Mecca. En Área de Historia Oral del Archivo Provincial de la Memoria de Córdoba, 6-11-2009.

- Entrevista a Domingo Bizzi, en Susana Roitman et. al., El torno y la molotov. Relatos e imágenes de la Córdoba obrera 60-70, Córdoba, Universitas, 2010

- Entrevista a Alfredo Curutchet, 1971, en Héctor Schmucler, J. Sebastián Malecki y Mónica B. Gordillo, El obrerismo de pasado y presente: Documento para un dossier no publicado sobre SiTraC-SiTraM, Córdoba, Eduvim, 2014.

- Entrevista a José Páez. Entrevistador: Diego Salerno. Buenos Aires, 1993.

- Entrevista a Sergio Ortiz. Entrevistador: Diego Salerno. Buenos Aires, 1993.

- Entrevista a Julio Oropel. Entrevistadora: Marcela Santucho. Córdoba, 2010. 